\title{
Lineage commitment in the immune system: the T helper lymphocyte grows up
}

\author{
Laurie H. Glimcher ${ }^{1,2,4}$ and Kenneth M. Murphy ${ }^{3}$ \\ ${ }^{1}$ Department of Immunology and Infectious Diseases, Harvard School of Public Health, Boston, Massachusetts 02115-6017 \\ USA; ${ }^{2}$ Department of Medicine, Harvard Medical School, Boston, Massachusetts 02115 USA; ${ }^{3}$ Department of Pathology, \\ Washington University School of Medicine, St. Louis, Missouri 63110 USA
}

Cells of the immune system provide particularly fruitful subjects for the study of lineage commitment. Both $\mathrm{T}$ and B lymphocytes undergo complicated patterns of differentiation from uncommitted, nonfunctional precursor cells to highly sophisticated effector cells. The development of the helper $\mathrm{T}$ lymphocyte is one of the most elegant examples of this. A little over a decade ago, Mosmann and Coffman (1989) discovered that naive mouse $\mathrm{CD}^{+} \mathrm{T}$ helper lymphocytes, upon receiving an antigenic stimulus, differentiate into two distinct subsets defined both by their function and by unique cytokine profiles. These subsets, $\mathrm{T}$ helper 1 (Th1) and T helper 2 (Th2) (Mosmann et al. 1986; Mosmann and Coffman 1989; Paul and Seder 1994; O'Garra 1998; Rengarajan and Glimcher 2000), are responsible for cell-mediated/inflammatory immunity and humoral responses, respectively (Fig. 1). This division of labor fits nicely with previous demonstrations that an organism tends to mount either a cell-mediated or humoral response, but not both, in response to pathogens. The function of $\mathrm{T}$ helper cells can largely be explained by the cytokines they secrete. Cytokines (or lymphokines) are small hormone-like polypeptides that have pleiotrophic biological activities in several cell types. Resting $\mathrm{T}$ cells do not transcribe cytokine genes, but they are rapidly induced upon coactivation through the T-cell receptor (TCR) and costimulatory receptors (Lenschow et al. 1996). Much progress has been made in identifying the signaling pathways and transcription factors that control Th1 and Th2 differentiation as shown schematically (Fig. 2a). This review will summarize what is currently known about the signals that regulate lineage commitment in $\mathrm{T}$ helper cells with a special focus on three subset-specific transcription factors, T-bet, GATA-3, and c-Maf, responsible for lineage commitment (Fig. 2b).

\section{Th cell cytokines, phenotype, and function}

The functional differences between the Th subsets can largely be explained by the activities of the subset-spe-

${ }^{4}$ Corresponding author.

E-MAIL lglimche@hsph.harvard.edu; FAX (617) 432-0084. cific cytokines produced. The hallmark cytokine of Th1 cells is interferon- $\gamma(\operatorname{IFN} \gamma)$, and Th1 cells also produce IL-2, TNF, and LT, cytokines that mediate delayed type hypersensitivity responses and macrophage activation. The signature cytokine of Th2 cells is interleukin-4 (IL4), and Th2 cells also secrete IL-5, IL-9, IL-10, and IL-13, cytokines that provide help to B cells and are critical in the allergic response (Arthur and Mason 1986; Paliard et al. 1988; Mosmann and Coffman 1989; Paul and Seder 1994). This paradigm extends to other species including human where clearcut human Th1 and Th2 clones have been generated (Romagnani 1992, 1994). However, simultaneous production of IL-2, IL-4, and IFN $\gamma$ can be observed in human helper cells (Paliard et al. 1988).

A host of surface antigens that are unique to, or preferentially expressed on, Th1 or Th2 cells have recently been identified. Th1-preferentially expressed genes include the IFN $\gamma$ receptor- $\beta$ chain, IL-12 receptor $\beta$ chain, IL-18 receptor, the P-selectin glycoprotein ligand-1, and the CXCR3 and CCR5 chemokine receptors (Davis et al. 1984; Bach et al. 1995; Borges et al. 1997; Szabo et al. 1997a; Bonecchi et al. 1998; Sallusto et al. 1998; Xu et al. 1998b). Markers preferentially expressed on Th2 cells include a novel IL-1-like molecule T1/ST2 and the chemokine receptors CCR3 (eotaxin receptor), CCR4, and CCR8 (Bonecchi et al. 1998; D'Ambrosio et al. 1998; Lohning et al. 1998; Sallusto et al. 1998; Xu et al. 1998a; Zingoni et al. 1998; Coyle et al. 1999; Hoshino et al. 1999; Townsend et al. 2000). T1/ST2 is a stable marker for Th2 cells in vivo that may be functionally important in the generation of Th2 responses. Antibodies against T1/ST2 attenuated eosinophilic inflammation in airways and suppressed Th2 cytokines in vivo (Lohning et al. 1998), and mice lacking T1/ST2 had impaired Th2 responses to Schistosoma mansoni. The preferential expression of these markers on effector Th1 and Th2 cells may be the consequence of ligand-induced events or of the cytokine milieu because surface antigens that will distinguish Th cells in the early stages of Th1 or Th2 differentiation have not yet been found. The best way to phenotypically distinguish the two subsets is by their unique cytokine profiles as determined by cellular stain- 
Figure 1. Signals that influence TH differentiation.
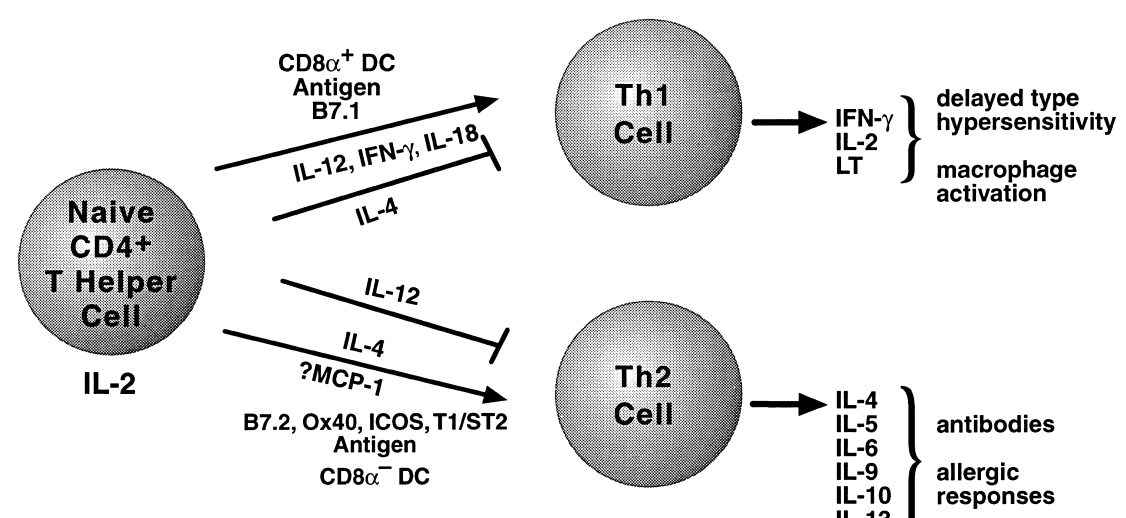

ing for IFN $\gamma$ and IL-4 or by a powerful new technique that allows detection of surface IFN $\gamma$ and IL-4 (Ouyang et al. 2000). We and others have also generated transgenic "knock-in" mice at the IL-4 locus (Riviere et al. 1998; Ho et al. 1999) that may prove useful in marking early Th2 cells.

\section{Factors that influence lineage commitment}

After differentiation and emigration from the thymus to the peripheral immune organs, $\mathrm{CD}^{+} \mathrm{T}$ helper cells are

A

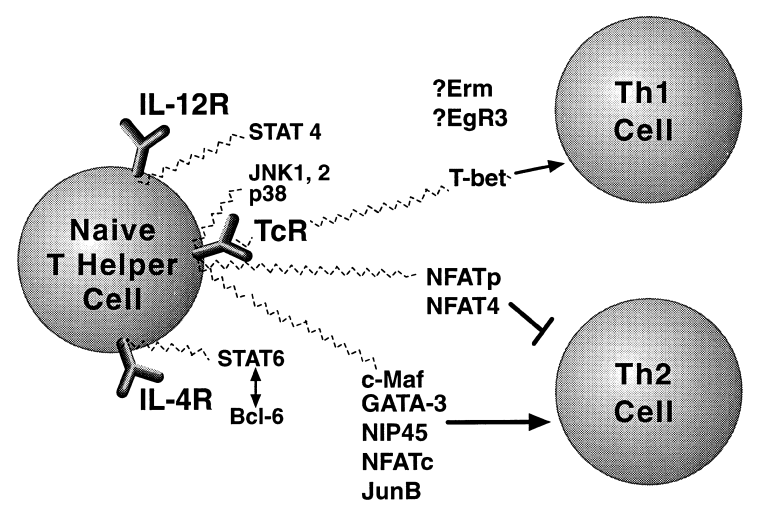

B

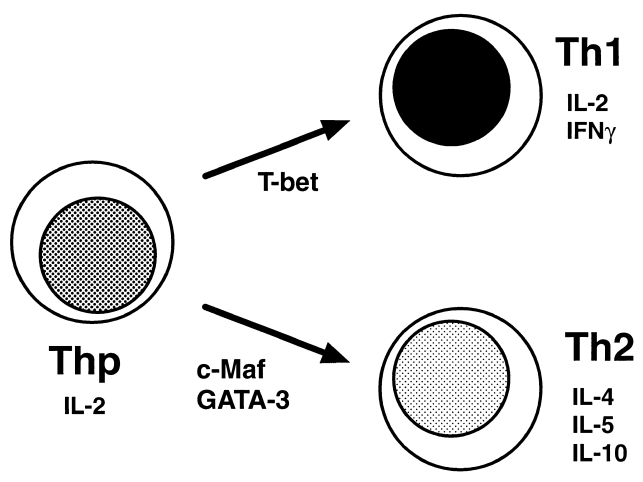

Figure 2. $(A)$ Transcription factors that influence Th differentiation. $(B)$ Tissue-specific factors that regulate $\mathrm{CD}^{+} \mathrm{T}$ helper cell differentiation. termed naive $\mathrm{T}$ helper precursor (Thp) cells. Thp cells are functionally immature and capable of secreting only IL2. Much has been learned about the signals that drive these naive Thp cells, which secrete only IL-2, to become Th1 or Th2 effector cells. Th1 and Th2 cells appear to derive from a common precursor that expresses the IL-4 gene (Kamogawa et al. 1993). Thp activation and differentiation in the periphery requires at least two separate signals. The first signal is delivered by the TCR/CD3, after its interaction with antigen/MHC on antigen presenting cells (APCs). The second signal is produced by a number of costimulatory or accessory molecules typified by the CD28/B7, OX40, and LFA-1/ICAM receptor-ligand pairs. Whether an immune response will be dominated by Th 1 versus $\mathrm{Th} 2 \mathrm{CD} 4^{+}$cells is clearly influenced by the nature of these two signals (Seder and Paul 1994). However, neither of these two signals is as potent a determinant of Th cell fate as the cytokine milieu itself.

$A P C$, antigen, costimulation Signal one is delivered by interaction of the TCR on a naive Thp cell with MHC/ antigen on an APC such as a dendritic cell. The recent identification of phenotypically distinct subsets of dendritic cells has revealed unique functions for these subsets in the development of Th cells (Maldonado-Lopez et al. 1999; Pulendran et al. 1999; Rissoan et al. 1999; Smith and Fazekas de St. Groth 1999). In the mouse, CD $8 \alpha^{+}$ lymphoid-like dendritic cells produce IL-12 and preferentially stimulate Th1 differentiation. Recently, a T-cell secreted factor called Eta1/osteopontin has been shown to drive Th1 differentiation by inducing IL-12 and inhibiting IL-10 secretion from APC (Ashkar et al. 2000). Eta1deficient mice fail to mount DTH responses to pathogens such as herpes simplex keratitis and Listeria monocytogenes. A second subset of myeloid-like CD8 $\mathrm{a}^{-}$DC have been shown to stimulate Th2 differentiation. The mechanism by which this occurs remains unclear because the APC counterpart cytokine of IL-12 for Th2 differentiation is not known, although IL-6 has been suggested as a candidate (Rincon et al. 1997). An intriguing possibility is that specific chemokines may polarize Thp cells, as evidenced by a recent report that MCP-1 deficient mice fail to mount $\mathrm{Th} 2$ responses (Gu et al. 2000). 
The influence of antigen structure and antigen dose in Th polarization has been reviewed recently (Constant and Bottomly 1997; Tao et al. 1997; O'Garra 1998). In particular, the use of altered peptide ligands has provided convincing evidence that the strength of the signal transmitted via the TCR influences lineage commitment, perhaps by controlling the duration or magnitude of $\mathrm{Ca}^{2+}$ fluxes (Sloan-Lancaster et al. 1997; Grakoui et al. 1999). The role of costimulatory molecules in Th cell skewing is clear as CD28 and B7 knockout mice have significantly reduced immune responses with especially pronounced defects in generating the Th2 compartment (Freeman et al. 1993; Green et al. 1994; Schweitzer et al. 1997). What is controversial is whether the two costimulatory molecules, B7-1 and B7-2, can differentially drive Th cell development (Kuchroo et al. 1995; Brown et al. 1996; Ranger et al. 1996; Nakajima et al. 1997; Subramanian et al. 1997). A third costimulatory receptor, ICOS, functionally related to CD28 and its ligand B7-H1 (Dong et al. 1999; Hutloff et al. 1999; Yoshinaga et al. 1999; Ling et al. 2000), is thought to preferentially stimulate Th2 differentiation. Th2 cells are also preferentially expanded by CD28-dependent OX40 signaling (Akiba et al. 2000; Lane 2000; Murata et al. 2000). Recently, an opposing role for the LFA-1/ICAM-1,2 interaction in regulating Th2 development has been demonstrated because blocking this interaction results in overproduction of Th2 cytokines (Salomon and Bluestone 1998).

Cytokines The cytokines themselves play the most critical role in $\mathrm{T}$ helper cell polarization. The two critical cytokines that control Th1 and Th2 differentiation are IL-12 and IL-4, respectively. These two cytokines enhance the generation of their own Th subset and simultaneously inhibit the generation of the opposing subset (Scott 1991; Maggi et al. 1992; Parronchi et al. 1992; Hsieh et al. 1993; Macatonia et al. 1993; Manetti et al. 1993; Powrie and Coffman 1993; Seder et al. 1993; Trinchieri 1993; Wu et al. 1993), events that likely occur at a precursor stage (Thp) because once established, Th1 and Th2 cells cannot revert (Scott 1991; Murphy et al. 1996). The requirement for these two cytokines has been demonstrated unequivocally by the phenotype of mice that lack these cytokines, cytokine receptors, or the effector molecules downstream of the receptors. IL-12, secreted by APC, activates the Stat4 signaling pathway, and mice lacking IL-12 or Stat4 do not have Th1 cells (Kaplan et al. 1996a; Magram et al. 1996; Thierfelder et al. 1996). Two other cytokines that influence Th1 development are IL-18, whose receptor is related to the IL-1 receptor family (Cerretti et al. 1992; Okamura et al. 1995; Gu et al. 1997), and IFNy (Scott 1991; Meraz et al. 1996). IFN $\gamma$ activates the Statl pathway (Meraz et al. 1996). Mice lacking IL-18 or Stat1 have defective in vivo Th1 responses (Meraz et al. 1996; Takeda et al. 1998). In contrast, mice that lack IL-4, IL-4 receptor, or Stat6, the downstream signaling molecule for the IL-4 receptor, fail to develop Th2 cells in response to most stimuli (Kuhn et al. 1991; Kopf et al. 1993; Kaplan et al. 1996b; Shimoda et al. 1996; Takeda et al. 1996; Noben-Trauth et al.
1997). The biologic function of another cytokine, IL-13, partially overlaps with IL-4 because, in some instances, IL-13 drives Th2 development and IgE synthesis in an IL-4-independent fashion (Minty et al. 1993; Punnonen et al. 1993; Barner et al. 1998; Cohn et al. 1998; Emson et al. 1998; McKenzie et al. 1998). IL-13 is especially important in the asthmatic response (Wills-Karp et al. 1998).

\section{Development of the Th1 lineage}

Signaling pathways Signaling pathways emanating from both the TCR and the IL- 12 receptor drive Th1 differentiation at least in part by inducing the expression of the Th1-restricted transcription factor T-bet described below (Fig. 3). The p38 MAP kinase pathway regulates IFN $\gamma$ production in $\mathrm{CD}^{+}{ }^{+} \mathrm{T}$ cells (Dong et al. 1998; Rincon et al. 1998; Yang et al. 1998) because p38 MAPK inhibitors and a dominant-negative p38 transgene reduced Th1 responses (Rincon et al. 1998). Targeted disruption of MKK3 (Lu et al. 1999) also diminished Th1 responses, but primarily by decreasing IL-12 production. The Jun $\mathrm{NH}_{2}$-terminal kinase (JNK) pathway has also been implicated in Th1 development or function. A substantial reduction in IFN $\gamma$ production was observed in JNK2-deficient T cells (Yang et al. 1998), although the decreased IFN $\gamma$ production may be secondary to impaired expression of IL-12R $\beta 2$ in JNK2-deficient T cells rather than a direct requirement for JNK2 in IFN $\gamma$ gene transcription.

IRF-1 family members also participate in Th1 development and IFN $\gamma$ production primarily, but perhaps not entirely, through controlling IL-12 production (Lohoff et al. 1997; Taki et al. 1997). Although IRF-1-deficient mice have reduced IL-12 production, there are conflicting studies on the ability of IL-12 to restore IFN $\gamma$ production in IRF-1-deficient CD4 ${ }^{+}$T cells (Lohoff et al. 1997; Taki et al. 1997). Furthermore, IL-12 signaling in T cells induces IRF-1 expression, apparently through activation of Stat4 (Coccia et al. 1999). Thus, IRF-1 expression may be downstream as well as upstream of IL-12.

Role of Stat4 in Th1 development Th1 development involves signaling through Stat4, cloned by homology to other STATs (Zhong et al. 1994) but later found to be

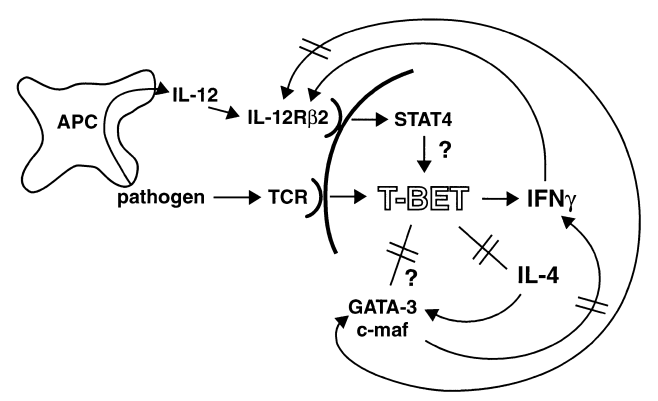

Figure 3. Transcription factors that control Th1 differentiation. 
dedicated to IL-12 signaling in the mouse (Jacobson et al. 1995). Stat4 activation was first correlated with IFNy expression by recognizing the loss of IL-12-induced Stat4 activation in Th2 cells (Szabo et al. 1995), and its role in Th1 development later proven using Stat4-deficient mice (Kaplan et al. 1996a; Thierfelder et al. 1996). Clearly not all IFN $\gamma$ production by $\mathrm{T}$ cells is Stat4-dependent (Kaplan et al. 1998; Carter and Murphy 1999). Stat6/Stat4 double-deficient T cells produce some IFNy (Kaplan et al. 1998), and CD8 ${ }^{+} \mathrm{T}$ cells are largely Stat4independent for TCR-induced IFN $\gamma$ production, in contrast to $\mathrm{CD}^{+} \mathrm{T}$ cells (Carter and Murphy 1999). Although Stat 4 is critical in the generation of Th1 cells, its role in directly controlling IFN $\gamma$ gene transcription is unclear. Stat 4 may act on the IFN $\gamma$ gene via cooperative binding to nonconsensus low-affinity STAT sites in the IFN $\gamma$ gene promoter and first intron (Xu et al. 1996), but TCR-activated Th1 cells produce IFN $\gamma$ without Stat 4 activation (Ouyang et al. 1999; Yang et al. 1999). In addition, IFN $\alpha$-induced Stat 4 activation in human T cells is not sufficient to activate IFN $\gamma$ transcription (Rogge et al. 1998). Although IL-12 activates Stat 1 and Stat3 as well as Stat4, only Stat4 is required for Th1 differentiation. Explanations for this selectivity might include induction of unique Stat4-activated targets or involve selective interactions with Stat4-interacting coactivators. Several STAT factors have been shown to interact with the general transcriptional coactivators p300/CBP (Bhattacharya et al. 1996; Zhang et al. 1996; Korzus et al. 1998).

Type I interferons in Th1 responses Although the control of human and mouse Th differentiation is quite similar, one important difference has emerged. In human $\mathrm{T}$ cells, the cytokine IFN $\alpha$, not IL-12, controls Th1 development and IFN $\gamma$ production (Parronchi et al. 1992; Brinkmann et al. 1993; Rogge et al. 1997). This is in contrast to the inability of IFN $\alpha$ to induce Th1 development in the mouse (Wenner et al. 1996; Rogge et al. 1998). Both IL-12 and IFN $\alpha$ activate Stat4 and induce Th1 development in human T cells, whereas only IL-12 exerts these effects in murine T cells (Rogge et al. 1998). Although IL-12 receptor expression appears to be modulated in the mouse, being lost in Th2 cells (Xu et al. 1998b), the constitutive expression of IFN $\alpha$ receptors on human $\mathrm{T}$ cells provides an attractive explanation for the observation that human $\mathrm{T}$ cells show less exclusive polarization of IFN $\gamma$ and IL-4 than mouse T cells.

IL-1 family cytokines and signaling in Th1 development IL-12 and IL-4 are considered the dominant factors in Th1 and Th2 development, but other factors, especially the cytokine IL-18, also contribute. Differential actions of IL-1 on T-cell subsets were recognized early on (Lichtman et al. 1988; Taylor-Robinson and Phillips 1994; Shibuya et al. 1998), and IL-1R-deficient mice display enhanced Th2 responses in vivo (Satoskar et al. 1998). More recently, IL-18, an IL-1-related factor (Ghayur et al. 1997; Gu et al. 1997; Fantuzzi et al. 1998), was shown to be a selective activator of IFN $\gamma$ in Th1, but not Th2, cells. IL-1 and IL-18 signaling pathways share similar components. Both IL-1 and IL-18 activate IRAK (Robinson et al. 1997), NF-кB in Th1 cells (Matsumoto et al. 1997; Robinson et al. 1997), and TRAF6 (Kojima et al. 1998). MyD88-deficient mice not only lose IL-1-induced function but also IL-18-mediated functions (Adachi et al. 1998). IRAK-deficient mice have defective IL-18-mediated natural killer (NK) and Th1-type responses to pathogens in vivo (Kanakaraj et al. 1999). In addition, potential IL-18 activation of the MAP kinase pathway has been reported (Tsuji-Takayama et al. 1997).

Powerful synergy between IL-12 and IL-18 for IFN $\gamma$ production was reported (Micallef et al. 1996; Kohno et al. 1997). IL-18-deficient mice (Takeda et al. 1998) show reduced LPS-induced IFN $\gamma$ production after priming with Propionibacterium acnes, and mice deficient in both IL-18 and IL-12 have a more severe defect in IFN $\gamma$ production than either strain alone. Although IL-18 is clearly important for IFN $\gamma$ production in vivo, its mechanism of action in T-cell development remained unclear. $\mathrm{O}^{\prime}$ Garra and colleagues clarified this issue by showing that IL-18 does not induce development of Th1 cells but acts after IL-12-induced Th1 development to increase IFN $\gamma$ produced by differentiated Th1 cells (Robinson et al. 1997). IL-12 and IL-18 together induced full IFN $\gamma$ production by Th1 cells, independently of stimulus through the TCR. The synergistic actions of IL-12 and IL-18 on the IFN $\gamma$ promoter were proposed to be mediated by a Stat 4 binding site and an adjacent AP-1 binding site (Barbulescu et al. 1998).

\section{Transcriptional regulation of Th1-specific cytokines}

IL-2 IL-2 is expressed exclusively in T lymphocytes and is the cytokine produced earliest during Th differentiation. It is the major cytokine produced by the naive Thp cell. Differentiated effector Th1, but not Th2, cells also produce IL-2 albeit at lower levels than primary, stimulated Thp cells. IL-2 expression is primarily controlled at the transcriptional level, although costimulation via CD28 regulates IL-2 expression post-transcriptionally, by increasing IL-2 mRNA stability (Umlauf et al. 1995). TCR engagement activates MAP kinase and $\mathrm{Ca}^{2+}$-dependent signaling pathways, both essential for IL-2 expression, and leads to the activation of several transcription factors including members of the nuclear factor of activated $T$ cells (NFAT) and activator protein 1 (AP-1) families (Durand et al. 1988; Shaw et al. 1988; Marx 1993; Northrop et al. 1994; Jain et al. 1995). In resting T cells, NFAT proteins reside in the cytoplasm in a phosphorylated state. Upon stimulation they are rapidly dephosphorylated by the phosphatase calcineurin and translocate into the nucleus where, in combination with AP-1 proteins, they activate the transcription of multiple cytokine genes, including IL-2 (Jain et al. 1995). The repression of cytokine gene transcription by the immunosuppressants cyclosporin A (CsA) and FK506 is explained by their blockade of calcineurin leading to inhibition of $\mathrm{Ca}^{2+}$-mediated, and hence NFAT-dependent, pathways 
(Emmel et al. 1989), as well as their blockade of JNK activation (Shibasaki et al. 1996).

The regulatory regions of the IL- 2 gene have been well delineated in vitro and have begun to be characterized in vivo as well. A 300-bp minimal promoter/enhancer region has been mapped that is sufficient for tissue-specific expression of the IL-2 gene in Th1 cells in vitro (Lederer et al. 1994). This region contains binding sites for multiple factors including inducible proteins like NFAT, AP-1 (Jun and Fos), and NF-кB (p50, p65, c-Rel) family members and constitutive factors like Oct proteins (Durand et al. 1988; Jain et al. 1995; Rooney et al. 1995b; Maggirwar et al. 1997; Shapiro et al. 1997; Ullman et al. 1991) (Fig. 4). Although the CD28 response element has been mapped and shown to bind NFAT proteins, NF- $\kappa$ B proteins such as c-Rel, ATF-1, CREB2, and HMG I(Y), it remains unclear which if any of these factors binds in vivo (Himes et al. 1996; Shapiro et al. 1998). Although the identity of the proteins bound to sites in this 300-bp promoter in vivo is not yet clear, the functional relevance of each of these sites in vitro has been established by point mutations that substantially impair transcriptional activity (Rooney et al. 1995b). In vivo footprinting of the IL-2 locus in T cells revealed a combinatorial interaction of multiple proteins on the IL-2 promoter/enhancer rather than autonomous binding of single factors (Rothenberg and Ward 1996). Although the 300-bp promoter/enhancer region is sufficient for high-level Th1- specific expression in vitro, this has not been borne out by studies in transgenic mice where at least $600 \mathrm{bp}$ of the IL-2 promoter has been required (Brombacher et al. 1994). This is consistent with earlier studies that identified DNase I hypersensitivity (HS) sites outside of this region (Siebenlist et al. 1986). Footprinting and DNase I HS studies revealed TCR-inducible T-cell-specific HS sites between -600 and -300 bp upstream of the transcriptional start site (Rothenberg and Ward 1996; Ward et al. 1998) and activation-inducible sites between -400 and -300 bp upon activation (Ward et al. 1998). Identification of the proteins binding to these regions in vivo may yield factors that influence chromatin accessibility and remodeling.

Nevertheless, it is important to note that, in contrast to IFN $\gamma$ and IL-4 as described below, the transcription factors that direct the tissue-specific expression of IL-2 have not yet been defined. None of the transcription factors described above is Th1 specific, and none, by itself, can account for the Th1-specific expression of IL-2. Thus, it is not possible to reconstitute the expression of IL-2 in a nonproducer cell as can be done for IFN $\gamma$ with T-bet and for IL-4 with c-Maf (Ho et al. 1996; Hodge et al. 1996a; Szabo et al. 2000). It is possible that Th1-specific expression of IL-2 may be accomplished by the precise temporal and spatial combination of proteins at the transcription complex or, more likely, by a single factor that has not yet been identified.

\section{The IL-4 Promoter}

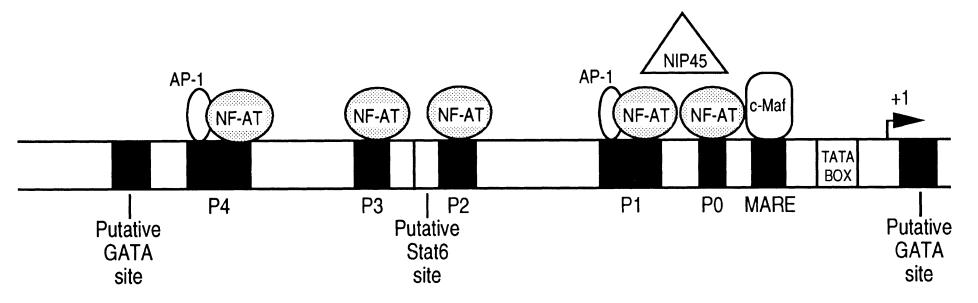

The IL-2 Promoter

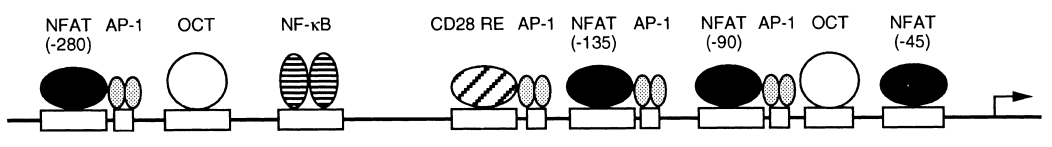

\section{IFN- $\gamma$ Regulatory Regions}

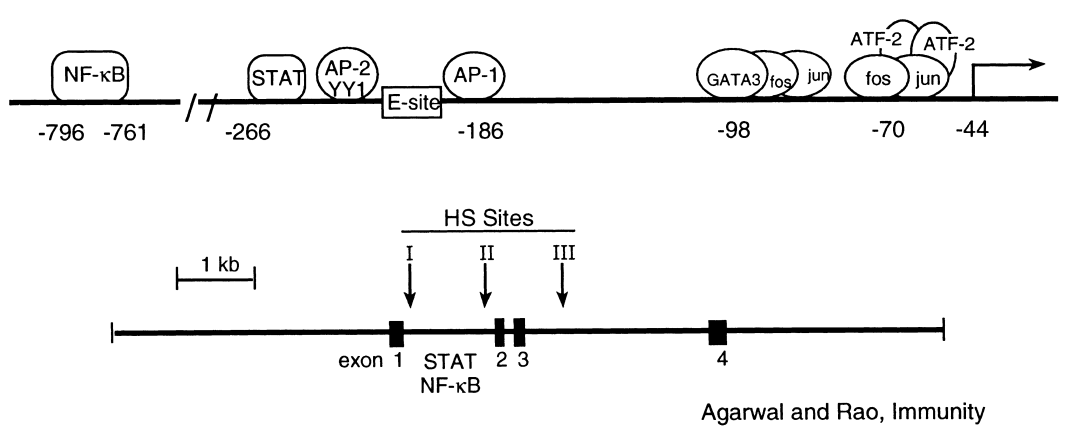

Figure 4. Regulating regions of cytokine genes. 
IFN- $\gamma$ Th1 cells, $\mathrm{CD}^{+}$cells, and NK cells are the major secretors of IFN $\gamma$ that is induced within $24 \mathrm{hr}$ after stimulation of naive cells (Lederer et al. 1996). Very little is known about the regulatory regions of the IFN $\gamma$ gene. For example, the location of elements that direct its tissue-specific expression has not been established in vitro or in vivo although early studies designated $8.6 \mathrm{~kb}$ as conferring $\mathrm{T}$ cell-specific expression (Agarwal and Rao 1998a). The Th1-specific regions within this sequence have not yet been identified. Reporter constructs containing $500 \mathrm{bp}$ or $3 \mathrm{~kb}$ of upstream sequence are active but are expressed in both Th1 and Th2 cells (Young et al. 1994).

The 500-bp region is induced by phorbol ester and ionomycin and inhibited by CsA in vitro. A fairly detailed analysis of sites within the proximal promoter has been performed using both mouse and human $\mathrm{T}$ cells as expression systems. Two essential regulatory elements that mirror the expression of the endogenous gene were identified between -108 and $-40 \mathrm{bp}$, the distal element (-96 to $-80 \mathrm{bp}$ ) being a consensus GATA motif that binds GATA-3 in vitro (Penix et al. 1993) and the proximal regulatory element $(-73$ to $-48 \mathrm{bp})$ capable of binding CREB, ATF-1, ATF-2, c-Jun, and Oct-1 proteins (Penix et al. 1996). The proximal element, when dimerized, recapitulates the inducibility and CsA sensitivity of IFN $\gamma$ in Jurkat $T$ cells and in transgenic mice although additional NFAT sites exist outside of the proximal regulatory element, and NFAT proteins transactivate and interact with these sites in vitro (Campbell et al. 1996; Aune et al. 1997; Sweetser et al. 1998). NF-кB proteins (c-Rel, p50, and p65) and possibly NFAT proteins bind to and transactivate regions in the first intron of the IFN $\gamma$ gene (Sica et al. 1997), and mice that express a dominant-negative IкB $\alpha$ transgene that inhibits NF- $\kappa \mathrm{B}$ have substantially impaired IFN $\gamma$ production (Aronica et al. 1999). Ying-Yang 1 (YY1) interacts with a negative regulatory element and was initially thought to inhibit IFN $\gamma$ expression (Ye et al. 1996) but was subsequently shown to also transactivate IFN $\gamma$ through binding to an element between the two NFAT sites (Sweetser et al. 1998).

Although a functional role for ATF-2, NF-кB, AP-1, GATA-3, NFAT, and Stat4 sites in the IFN $\gamma$ promoter or introns has been demonstrated, these factors cannot account for tissue-specific expression (Penix et al. 1993, 1996; Young et al. 1994; Xu et al. 1996; Ye et al. 1996; Barbulescu et al. 1997; Sica et al. 1997; Zhang et al. 1998b). Several reports have suggested that tissue-specific regulatory elements are located in the first and third introns as demonstrated by Th1-preferential DNase I hypersensitive sites as discussed below, but the actual cis elements responsible have not yet been identified (Young et al. 1994; Agarwal and Rao 1998b).

T-bet, a transcription factor that controls IFNy transcription and Th1 lineage commitment The approach that several laboratories took to unravel the genetic programs that controlled Th lineage commitment was to isolate the factors that accounted for the Th-subset selective expression of IFN $\gamma$ and IL-4, reasoning that such factors should be important in specifying lineage fate. This search resulted in the isolation of one factor, T-bet, that is Th1 specific and controls IFN $\gamma$ gene transcription, and two Th2-specific factors, GATA-3 and c-Maf that control IL-4 gene transcription.

Very little was known about the control of IFN $\gamma$. The two transcription factors whose absence results in a failure to generate the Th1 compartment and hence IFN $\gamma$ are Stat4 (Kaplan et al. 1996a; Thierfelder et al. 1996) and IRF-1 (Lohoff et al. 1997; Taki et al. 1997), neither of which is Th1 specific. Although Stat4, the downstream signaling molecule for IL-12, is clearly important in driving Th1 differentiation from naive Thp cells, it does not appear to be required in primed Th1 cells /Carter and Murphy 1999). The absence of Th1 cells in IRF-1-deficient mice can be attributed to IL-12 deficiency because IRF-1 directly regulates the IL-12 gene (Lohoff et al. 1997; Taki et al. 1997). A new member of the Ets family called ERM is both Th1 specific and is induced by IL-12 in a Stat4-dependent manner, but its function is as yet unknown (Ouyang et al. 1999).

T-bet was isolated using an IL-2 promoter-reporter and a cDNA library prepared from activated Th1 cells in a yeast one-hybrid screen. Several independent clones obtained all proved to encode the same gene, a novel member of the T-box family of transcription factors. The gene was named T-bet for $\underline{T}$-box expressed in $\underline{T}$ cells. The T-box family, whose founding member is Brachury or $T$ for short-tailed mutation in mice (Herrmann et al. 1990), is defined by the presence of a highly conserved T-box DNA-binding domain (for review, see Meisler 1997; Papaioannou 1997; Smith 1997). There have now been isolated multiple members of this family in species ranging from nematodes to humans, and the T-box domain of T-bet is most similar to the mouse gene T-brain (Bulfone et al. 1995) and the Xenopus gene eomesodermin (Rao 1994). Several of the T-box proteins play important roles in mesoderm development. Mutations in one allele of the human $T b x 5$ and $T b x 3$ genes are responsible for the human congenital diseases Holt-Oram syndrome and ulnar-mammary syndrome, respectively (Bamshad et al. 1997; Basson et al. 1997; Li et al. 1997; Spranger et al. 1997), whereas the chicken $T b \times 4$ and $T b x 5$ genes govern limb bud identity (Rodriguez-Esteban et al. 1999; Takeuchi et al. 1999). There are several consensus T-box binding sites in the IL-2 promoter and in both the promoter and third intron of the IFN $\gamma$ gene, where the Th1-specific DNAse I hypersensitive site is located.

Expression and function analyses of T-bet revealed the following: T-bet is expressed only in Th1 cells and in NK cells, the known producers of IFN $\gamma$. In these cells, T-bet transcripts and protein are rapidly induced upon signaling through both the TCR and the IL-12 receptor (S. Szabo and L.H. Glimcher, unpubl.). The expression of $\mathrm{T}$-bet completely correlates with the expression of IFN $\gamma$ in all cells examined including B cells that can be induced to produce T-bet and IFN $\gamma$ upon stimulation via the CD40 receptor in the presence of IL-12 and IL-18 (Yoshimoto et al. 1997). Transient transfection assays in a Th0 non-IFN $\gamma$-producer lymphoma revealed that T-bet 
was a potent transactivator of the IFN $\gamma$ gene and a repressor of the IL-2 gene. Provision of T-bet to these cells induced endogenous IFN $\gamma$ production. To assess the effect of T-bet on primary T cells, CD4 T cells were transduced with a bicistronic T-bet/GFP retroviral construct. The function of T-bet was determined in unskewed CD4 T cells, developing Th2 cells, and in fully polarized CD4 and CD8 T cells. Remarkably, in all cases, provision of T-bet resulted in the generation of large numbers of IFN $\gamma$-producing Th1 cells that expressed Th1 lineage markers. Most exciting, the effect of T-bet expression was twofold. It not only induced the production of IFNy but also simultaneously shut off the production of the Th2 cytokines IL-4 and IL-5. The expression of IL-2 was also reduced, consistent with a role for T-bet in driving differentiation. These effects were observed in early developing Th 2 cells and also in fully committed Th2 and Tc2 cells. T-bet is therefore a master regulator of Th1 lineage commitment and accomplishes this function both by activating Th1-inducing genetic programs and by terminating the opposing Th2-inducing genetic programs. Much more remains to be learned about the function and mechanism of the action of T-bet. The analysis of T-bet-deficient and overexpressor transgenic mice should prove informative.

\section{Development of the Th2 lineage}

Signaling pathways Two major signaling pathways drive Th2 differentiation: TCR and IL-4 receptor (Fig. 5). As discussed below, signals emanating from the TCR activate the transcription of two Th2-specific factors, cMaf and GATA-3, and also regulate the expression and the activation of the NFAT and AP-1 transcription factors. Upon signaling through the IL-4 receptor, Stat6 is recruited to bind to the cytoplasmic domain of the Il-4 receptor where it is then phosphorylated by Jak 1 and Jak3 kinases leading to Stat6 dimerization and translo-

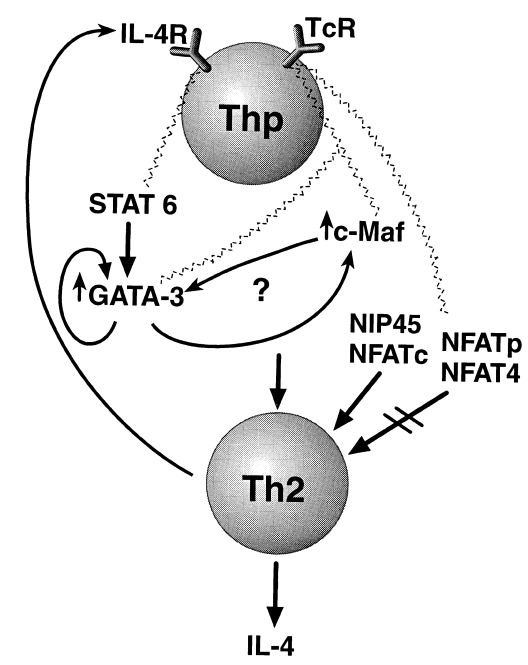

Figure 5. Transcription factors that control $\mathrm{TH} 2$ differentiation. cation to the nucleus (Hoey and Grusby 1999). Although it is unlikely that Stat6 itself directly controls IL-4 gene transcription to any significant degree (Lederer et al. 1996), it does activate a number of IL-4 target genes such as germ-line IgE gene transcription and switch recombination (Linehan et al. 1998), class II MHC, IL-4R, CD23 (Kaplan et al. 1996b; Shimoda et al. 1996; Takeda et al. 1996), and GATA-3 (Ouyang et al. 1998). Ectopic expression of an inducible, activated Stat 6 into developing Th1 cells induces c-Maf and GATA-3 with subsequent expression of IL-4 (Kurata et al. 1999). There is controversy about whether the JNK kinase pathway, another signaling pathway, regulates Th differentiation. Mice that lack JNK1 or JNK2 have been reported by one group to have increased Th2 and defective Th1 differentiation. Enhanced Th2 and normal Th1 responses were found in JNK1-deficient T cells (Dong et al. 1998), when T cells were activated under neutral in vitro conditions (Dong et al. 1998; Yang et al. 1998). However, the Th2 skewing observed in $\mathrm{JNK}^{-/-}$mice was not observed in an independently generated strain of JNK2-deficient mice (Sabapathy et al. 1999).

Stat6-independent pathways of Th2 differentiation do exist (Kaplan et al. 1999; Ouyang et al. 2000). BCL-6, a transcriptional repressor, inhibits Stat6 activity by competing for the Stat6 binding sites (Dent et al. 1997). Mice lacking BCL-6 display a profound Th2 phenotype (Dent et al. 1997). BCL-6 may control Th cell generation in both IL-4- and Stat6-independent manners as evidenced by the continuing Th2 phenotype of mice that lack both IL-4 and BCL-6 or both Stat6 and BCL-6 (Dent et al. 1997, 1998). c-Maf and NFAT proteins are also attractive candidates for factors responsible for Stat6-independent IL-4 production because they themselves are not Stat6 responsive. Nevertheless, although Stat6-independent pathways for IL-4 production exist, there can be little doubt of the critical role of this factor in generating the Th2 compartment in vivo as evidenced by the phenotype of mice lacking Stat6 (Kaplan et al. 1996b; Shimoda et al. 1996; Takeda et al. 1996).

\section{Transcriptional regulation of Th2-specific cytokines}

IL-4 The expression of IL-4 is restricted to a subset of $\alpha \beta$ CD4 (Th2) and CD8 (Tc2) T cells, NK T cells, $\gamma \delta \mathrm{T}$ cells, mast cells, basophils, and eosinophils (Abbas et al. 1996). Naive Thp cells express IL- 4 mRNA by $24 \mathrm{hr}$ after stimulation via the TCR, and levels peak at $48 \mathrm{hr}$ (Lederer et al. 1996). Studies in transgenic mice established that $3 \mathrm{~kb}$ of the IL-4 promoter conferred expression that mirrored endogenous IL-4 expression (Todd et al. 1993). Later studies that generated a series of IL-4 promoter transgenics demonstrated that the -741 - to +60-bp region was preferentially expressed in Th2 cells. A trimer of the region spanning an NFAT-AP-1 site (-88 to -61) was moderately Th2 specific. As for the IL-2 promoter, however, expression was low relative to endogenous IL-4 suggesting the presence of enhancer elements outside of the promoter (Wenner et al. 1997). 
The promoter region of the IL-4 gene has been studied in vitro by several groups (Abe et al. 1992; Bruhn et al. 1993; Chuvpilo et al. 1993; Szabo et al. 1993; Todd et al. 1993; Kubo et al. 1994b; Rooney et al. 1994, 1995a; Tara et al. 1995; Weber et al. 1998). Similar to IL-2, IL-4 promoter activity is anti-CD3, phorbol ester and $\mathrm{Ca}^{2+}$ ionophore inducible, and CsA inhibitable (Todd et al. 1993; Kubo et al. 1994a,b). Deletions of the murine IL-4 5' sequence established that $87 \mathrm{bp}$ of the proximal promoter conferred cell-specific and activation-dependent transcription in vitro (Bruhn et al. 1993; Szabo et al. 1993; Lederer et al. 1994). Extensive mutational analyses identified five NFAT sites, two of which are composite NFAT/AP-1 sites, within the proximal promoter that are critical for inducible IL-4 expression (Chuvpilo et al. 1993; Brown and Hural 1997; Szabo et al. 1997b). Mutations in each of these sites severely impaired promoter activity in vitro (Chuvpilo et al. 1993; Szabo et al. 1993; Todd et al. 1993; Hodge et al. 1995; Rooney et al. 1995b). Each of these sites bind NFATc1 and NFATc2 (Timmerman et al. 1997), and two of them also bind AP-1 proteins such as Fra-1, Fra-2, JunB, and JunD in an NFAT-dependent manner (Hodge et al. 1995; Rooney et al. 1995a). Although NFAT and AP-1 family proteins cannot explain Th2-specific IL-4 gene expression (Rooney et al. 1994), the phenotype of mice that lack one or more of the NFAT proteins has revealed an extremely important role, as detailed below, for this family in controlling cytokine gene expression, especially in Th2 cells. There may also be an especially important role for the AP-1 family member JunB in driving Th2 differentiation (Li et al. 1999).

NFAT NFAT was first identified as a TCR-inducible factor that regulated the IL-2 gene (Durand et al. 1988; Shaw et al. 1988; Crabtree 1989; Rao et al. 1997). NFAT proteins also regulate the promoters of multiple other cytokine genes expressed in T cells, including IL-4, GMCSF, IL-3 and TNF $\alpha$ (Miyatake et al. 1991; Chuvpilo et al. 1993; Goldfeld et al. 1993; Masuda et al. 1993; Rooney et al. 1994, 1995a; Cockerill et al. 1995). Isolation of the genes encoding these proteins has yielded four NFAT family members called NFATc1 (also called NFATc, NFAT2), NFATc2 (also called NFATp, NFAT1), NFATc3 (NFAT4 and NFATx), and the nonlymphoid NFATc4 (NFAT3) that are highly homologous within a region distantly related to the Rel domain (McCaffrey et al. 1993; Northrop et al. 1994; Hoey et al. 1995; Masuda et al. 1995). NFAT family members differ markedly in amino- and carboxy-terminal regions (Luo et al. 1996), and this, together with their differing tissue distribution and response to stimuli (Hoey et al. 1995; Ranger et al. 1998b), suggested that their functions might differ, as indeed proved to be the case.

Although the three lymphoid NFAT proteins are expressed in both Th1 and Th2 cells (Ranger et al. 1998b), the phenotype of single NFATc1- and NFATc2-deficient mice suggests that NFAT proteins might reciprocally regulate Th cytokines and consequently the Th1/Th2 balance. This turned out to be the case for NFAT-regu- lated Th2 cytokine production. T cells from mice lacking NFATc1 in the lymphoid system have reduced IL-4 production (Ranger et al. 1998a; Yoshida et al. 1998), consistent with a function of NFATc1 as a direct transcriptional activator of the IL-4 gene. Conversely, NFATc2 and NFATc3 negatively control proliferative responses, Th2 cell formation, and lymphocyte activation as revealed by the phenotype of mice lacking these genes (Hodge et al. 1996b; Xanthoudakis et al. 1996; Kiani et al. 1997; Oukka et al. 1998). Mice lacking NFATc2 display a moderate increase in Th2-type cytokines (Hodge et al. 1996b; Xanthoudakis et al. 1996). Mice lacking NFATc2 display a moderate increase in Th2-type cytokines (Hodge et al. 1996b; Xanthoudakis et al. 1996). Although mice lacking NFATc3 have normal cytokine production (Oukka et al. 1998), the very dramatic phenotype of mice lacking both NFATc2 and NFATc3 (DKO mice) proved that these two members had redundant function (Ranger et al. 1998b). These DKO mice had massive overproduction of Th2 cytokines with concomitant extreme elevations in levels of IgG1 and IgE, immunoglobulins whose production is IL-4 dependent. The clinical consequences of this Th1/Th2 imbalance were severe allergic blepharitis and interstitial pneumonitis characterized by influx of eosinophils and mast cells.

The constitutive localization of NFATc1 to the nucleus in the DKO T cells is consistent with unopposed transactivation of IL-4 by NFATc1 (Ranger et al. 1998a; Yoshida et al. 1998), which likely acts in concert with the Th2-specific transcription factors c-Maf and GATA-3 (Ho et al. 1996; Zheng and Flavell 1997) to drive IL-4 gene transcription. Although it is possible that the Th2 phenotype of the NFAT DKO is explained by a repressor function of NFATc2, it more likely reflects the dysregulation of additional, as yet unknown, NFAT target genes, critical in regulating the response of Thp and Th2 cells to TCR and cytokine receptor signaling.

\section{GATA-3 and c-Maf: Th2-specific transcription factors}

Substantial progress has been made in identifying the transcription factors responsible for the tissue-specific expression of the IL-4 gene in Th2 cells (Szabo et al. 1997b; Glimcher and Singh 1999; Glimcher et al. 1999) (Figs. 4 and 5). Two Th2-specific factors, the c-Maf protooncogene and the GATA-3 zinc finger factor, have been identified (Ho et al. 1991, 1996; Ting et al. 1996; Zhang et al. 1997; Zheng and Flavell 1997). Non-Th2-specific factors such as Stat6, NFAT proteins (Durand et al. 1988; Shaw et al. 1988; Crabtree 1989; McCaffrey et al. 1993; Northrop et al. 1994; Hoey et al. 1995; Masuda et al. 1995; Rao et al. 1997), and a novel nuclear antigen, NFAT-interacting protein $45 \mathrm{kD}$ (NIP45) (Hodge et al. 1996a), also help to regulate IL-4 production.

GATA-3 The zinc finger protein GATA-3 was initially cloned as a T-cell-specific transcription factor that bound to the Ta3 element of the TCR $\alpha$ gene enhancer (Ho et al. 1991). Deletion of the GATA-3 gene produces lethal abnormalities of the central nervous and hemato- 
poietic systems (Pandolfi et al. 1995), whereas mice lacking GATA-3 in the lymphoid system do not generate $T$ cells because GATA-3-deficient thymocytes arrest at the immature double-negative stage (Ting et al. 1996; Hendriks et al. 1999). A key discovery by two groups was the selective expression of GATA-3 in Th2 cells (Zhang et al. 1997; Zheng and Flavell 1997). Ectopic expression of a GATA-3 transgene led to increased levels of Th2 cytokines, whereas a dominant-negative GATA-3 transgene inhibited Th2 differentiation (Zheng and Flavell 1997; Zhang et al. 1999). GATA-3 directly controls IL-5 gene expression through binding to and transactivating elements in the region -70 to -59 (Siegel et al. 1995; Zhang et al. 1997, 1998a; Lee et al. 1998). GATA-3 probably does not directly bind to and transactivate the IL-4 promoter (Zhang et al. 1997, 1998a). Rather, several genomic regions within the IL-4/IL-13 locus have GATA-3dependent enhancer activity (Ouyang et al. 1998) suggesting GATA-3 may augment expression of IL-4 or IL13 via interactions at sites distant from the proximalpromoter.

In addition to increasing expression of Th2-selective cytokines, GATA-3 inhibits Th1 development independently of IL-4, perhaps in part by inhibition of IL-12R $\beta 2$ expression (Ouyang et al. 1998). Although GATA-3 is a Stat6-inducible gene, the developmental program initiated by GATA-3 can operate independently of Stat6 (Ouyang et al. 2000). When GATA-3 was expressed by retrovirus in Stat6-deficient $\mathrm{T}$ cells, all components of Th2 development were observed, including induction of Th2 cytokines, inhibition of Th1 cytokines, induction of c-Maf, and the formation of DNase I hypersensitive sites in the IL-4 locus. In addition, the endogenous GATA-3 gene was observed to be induced in these cells, despite the addition of IL-12 to the culture, normally a signal that inhibits GATA-3 expression (Ouyang et al. 1998). These results suggest a pathway of GATA-3 autoactivation, which could provide a mechanism for acquisition of the IL-4 independence that develops in Th2 cells described by Paul and colleagues (Huang et al. 1997).

The potential importance of this Stat6-independent pathway has been brought out by two recent studies. First, Jankovic et al. (2000) reported that Th2 cells can develop both in vivo in response to $S$. mansoni infection even in T cells lacking Stat6 or IL-4 receptor, suggesting the existence of an unrecognized pathway stabilizing Th2 development once these cells have emerged. Second, Finkelman and colleagues (2000)showed that in the primary response to pathogens, Stat6-deficient mice generated wild-type IL-4 responses, delineating a requirement for Stat6 in only the secondary response. These findings are all consistent with a model in which the initial expression of GATA-3 can be independent of IL-4 and Stat 6 activation but is repressible by IL-12; in the absence of such repression, GATA-3 can be induced through Stat6-independent autoactivation to induce the development of the Th2 phenotype.

c-Maf c-Maf was isolated using a yeast two hybrid screen with NFATc1 as bait and cDNAs from activated
Th2 cells as library (Ho et al. 1996). c-Maf, the cellular homolog of the avian viral oncogene v-maf, is a member of the AP-1 family of basic region/leucine zipper factors and binds to a consensus site (MARE) in the proximal IL-4 promoter. The expression of c-Maf is limited to Th2 cells, and its own expression is induced by signals transmitted via the TCR. Ectopic expression of c-Maf in all cells tested including yeast potently activates the IL-4 promoter. In $\mathrm{CD}^{+} \mathrm{T}$ cell lines prepared from patients with atopic disease, c-Maf is expressed at very high levels in Th2 clones but minimally in Th0 clones that produce IFN $\gamma$ and very little IL-4. Extremely strong evidence for the critical role of c-Maf in controlling IL-4 production has been gathered in vivo with the production of c-Maf overexpressor transgenics (Ho et al. 1998) and most convincingly with mice that lack c-Maf (Kim et al. 1999). c-Maf transgenic mice have an increased Th2 immune response in vivo and in vitro that can be ablated by backcrossing onto an IL-4-deficient background (Ho et al. 1998). Targeting of the c-Maf locus revealed severely impaired IL-4 production in the absence of c-Maf (Kim et al. 1999). These data provide very strong evidence that c-Maf is required for the production of IL-4 in vivo. However, the provision of c-Maf to mature effector Th1 cells cannot allow them to produce IL-4, suggesting that other factors such as Stat6 or GATA-3 may also be required.

An attractive overall schema (Fig. 5) suggests that signals through the TCR activate both c-Maf and GATA-3 as well as NFATc1 transcription factors, whereas IL-4 signaling induces GATA-3 and Stat6 activity. GATA-3 is autoregulatory (Ouyang et al. 2000), and it is possible that GATA-3 and c-Maf regulate each other in an autocrine loop, resulting in IL-4 production. GATA-3 downregulates expression of the IL-12R $\beta 2$ chain, whereas both GATA-3 and c-Maf repress IFN $\gamma$ production in Thp cells thus inhibiting the Th1 pathway (Ho et al. 1998; Ouyang et al. 2000).

\section{DNA replication and monoallelic cytokine gene expression}

The above discussion has emphasized signaling and transcriptional control of cytokine expression underlying a predominantly instructional model of $\mathrm{T}$ helper development. However, certain recent results have raised the issue of whether $\mathrm{T}$ helper commitment might not rely on stochastic or selective processes. Cytokine-driven responses in bulk populations do not necessarily distinguish between instructive or selective models of $\mathrm{T}$ cell differentiation. Recently, Coffman and Reiner (1999) have outlined three competing models of T helper development: instructive differentiation, selective differentiation, and a hybrid instructive/selective model. In the first model, all daughter cells of uncommitted progenitors respond to specific differentiating signals to acquire one particular developmental state. In the second, daughter cells of a progenitor adopt multiple development states in a random or stochastic manner, which later appears to polarize only by selective outgrowth of one cell type in responses to "polarizing" cytokines. 
Their hybrid model adds an effect of cytokines on altering the ratio in the initial developmental fates but retains the component of selective outgrowth in response to cytokines for achieving polarization.

Examining the stability or reversibility in bulk cultures reveals the potential for early reversibility and of heterogeneity but does not address issues of single cell fate determination (Murphy et al. 1996; Coffman et al. 1999|. Experiments using a lineage ablation approach, in which the IL-4 promoter drove expression of thymidine kinase (Kamogawa et al. 1993; Minasi et al. 1993; Nakamura et al. 1997), suggested that precursors to both Th1 and Th2 cells could proceed through a stage where the IL-4 promoter was active. Favoring the early commitment to the Th2 pathway is the rapid loss of a functional IL-12 receptor (Szabo et al. 1997a). Early Th1 populations, in contrast, exhibit greater reversibility (Mocci and Coffman 1995, 1997; Szabo et al. 1997a) due perhaps to uncommitted precursors within the early Th1 population (Mocci and Coffman 1997).

The possibility of epigenetic regulation of cytokine expression has recently sparked a renewed interest in noninstructional models of $\mathrm{T}$ helper development. Monoallelic expression using polymorphic IL-2 alleles from $\mathrm{F}_{1}$ mouse strains was revealed in both $\mathrm{T}$ cell clones and primary $\mathrm{T}$ cells to occur in a substantial fraction of $\mathrm{T}$ cells (Hollander et al. 1998), suggesting that alleles of IL-2 were not activated uniformly in all T cells. Similar findings for IL-4 alleles in Th2 cells were later reported (Bix and Locksley 1998), and these observations extended using reporter genes or knock-ins targeted to both the IL-2 (Naramura et al. 1998) and IL-4 loci (Riviere et al. 1998), allowing individual alleles to be examined in early populations of developing TCR transgenic $\mathrm{T}$ cells. In contrast to earlier findings, however (Hollander et al. 1998), biallelic expression of both IL-2 and IL-4 was observed as the predominant pattern in T-cell activation (Naramura et al. 1998; Riviere et al. 1998). The level of T-cell activation could also alter the distribution between monoallelic and biallelic expression (Riviere et al. 1998). These data favor a model in which activation of alleles is a stochastic process whose probability depends on TCR signal strength.

Reiner and colleagues have proposed that cell cycle is a more important regulator of $\mathrm{T}$ helper development than instructive cytokine signals based on distinct requirements for numbers of cell division in initiating cytokine expression (Bird et al. 1998). Naive T cells were immediately capable of producing IL-2, but IFN $\gamma$ and IL-4 production correlated with the number of cell divisions after activation, IFN $\gamma$ requiring only one to two cell divisions, but IL-4, four divisions. Similar results reported for cytokines that are not differentially expressed among Th1 and Th2 cells, such as IL-3 /Gett and Hodgkin 1998), implied that these differences may not control Th1/Th2 commitment. Furthermore, a very recent analysis (Richter et al. 1999) provided evidence against a strict cell-division model and in favor of an instructional model in which the epigenetic changes induced by TCR and IL-4R signaling are required for cyto- kine gene expression. This study found that naive T cells were capable of initiating IL-4 production after priming even when cell division was blocked as long as entry into the $S$ phase of the cell cycle was allowed. Once again, the required epigenetic changes appeared to be induced by cytokines, consistent with an instructional model of development.

\section{Role of chromatin structure}

Genomic DNA is packaged into nucleosomes, which then form higher order chromatin structures. Chromatin remodeling is accompanied by changes in nucleosomal positioning, an event that is ATP dependent. It has been suggested that cytokine gene loci, including IL-2, IL-4, IL-12, IL-13, IFN $\gamma$, and GM-CSF, undergo changes in chromatin structure that allow access to gene-specific transcription factors, likely mediated in part through acetylation of histones. Distal control regions such as enhancers and LCRs have been shown to regulate accessibility to gene loci by regulating chromatin structure (Ernst and Smale 1995). The location of regions that control these changes have been identified in cytokine genes using both assessment of CpG methylation status and DNase I hypersensitivity assays since transcriptionally active chromatin is hypomethylated and is more accessible to nucleases (Agarwal and Rao 1998a; Kadonaga 1998; Takemoto et al. 1998; Agarwal et al. 1999). The most complete information on the role of chromatin remodeling in the regulation of cytokine genes is available for two cytokines, IL- 4 and IFN- $\gamma$, and is summarized below and reviewed more thoroughly by Rengarajan and Glimcher (2000).

Regulation of the IL-4 and IFN- $\gamma$ loci Several observations suggested that the IL- 4 gene was regulated at the level of chromatin structure. First, in vitro analyses had indicated that only $157 \mathrm{bp}$ of the proximal IL-4 promoter was required for tissue-specific expression in Th2 cells. Nevertheless, in vivo, the proximal $800 \mathrm{bp}$ of the promoter was required to confer significant Th2-selective expression of an IL-4 promoter-reporter transgene (Wenner et al. 1997). However, neither $800 \mathrm{bp}$ nor up to $3 \mathrm{~kb}$ of sequence were sufficient to achieve expression equivalent to the endogenous IL-4 gene, suggesting the presence of additional elements for optimal expression (Todd et al. 1993). Second, differentiated, effector Th2 cells produce IL-4 more rapidly and at higher levels than naive Thp cells, implying that the IL-4 regulatory regions are more accessible or "poised" in effector, but not in naive, T cells (Reiner and Seder 1999).

Evidence for chromatin remodeling In both mouse and human chromosomes, the Th2 cytokine genes IL-4, IL-5, and IL-13 are clustered together within $150 \mathrm{~kb}$, consistent with the notion that these genes compose a single chromosomal locus that may be controlled by long-range modulation of chromatin structure. Rao and colleagues (Agarwal and Rao 1998b) provided evidence in favor of this model by using both methylation and DNase I hy- 
persensitivity assays to identify regions in the IL-4/IL-13 locus that responded to stimulation through the TCR. Differentiated Th2 cells and established Th2 clones had an accessible chromatin structure as evidenced by the presence of five clusters of HS sites over the IL-4 locus. Naive $\mathrm{T}$ helper cells, in contrast, like Th1 cells, possessed only one of the five HS sites. Within $48 \mathrm{hr}$ of antigen activation, naive Thp rapidly acquired the chromatin phenotype of differentiated Th2 cells, implicating these regions in important regulatory functions (Agarwal and Rao 1998b). The acquisition of these sites was dependent on both IL-4 and Stat6 (Agarwal and Rao 1998b). The Th2-specific transcription factor GATA-3 induced the same changes when transduced into differentiated Th1 cells or Stat6-deficient cells, indicating that GATA-3 acts to remodel this locus downstream of Stat6 (Ouyang et al. 2000). Furthermore, naive Thp cells possessed a hypermethylated IL-4 locus, whereas differentiated Th2 cells display decreased CpG methylation at the IL-4 locus. This latter result is consistent with the observation that treatment of naive Thp cells with trichostatin A and 5-azacytidine (histone deacetylase and methylase inhibitors, respectively) accelerates the kinetics of IL-4 production (Bird et al. 1998). Factors like GATA-3 and Stat6 may directly remodel chromatin structure to allow TCR-induced factors like c-Maf and NFAT to access their specific binding sites in the IL-4 locus and promote rapid transcription of IL-4 (Agarwal and Rao 1998b); NFAT proteins may also directly alter chromatin configuration. Mice that lack both NFATc2 and NFATc3 vastly overproduce Th2 cytokines and display a highly allergic phenotype (Ranger et al. 1998b) suggesting that NFAT proteins may help regulate the balance between the active/inactive state of the IL-4/IL5/IL-13 locus during the initiation of Th2 differentiation.

Although chromatin remodeling may also be important for the IFN $\gamma$ gene, less is known about this locus than the IL-4 locus. Tissue (Th1)-specific DNase I HS regions have been identified in both the first and third introns of the IFN $\gamma$ gene (Young et al. 1994; Agarwal and Rao 1998b), and these assays also demonstrate alterations of the IFN $\gamma$ locus in naive Th1 cells compared with Th2 cells (Agarwal and Rao 1998b). The methylation patterns of the IFN $\gamma$ locus have also been analyzed during $\mathrm{T}$-cell differentiation. IFN $\gamma$-producer cells like Th1 and $\mathrm{CD}^{+} \mathrm{T}$ cells display hypomethylation that appears to be a stable, long term, inheritable trait (Young et al. 1994; Fitzpatrick et al. 1999), whereas the same locus is methylated in Th2 cells. The assembly of Th1-specific transcription factors may remodel the chromatin in a configuration that facilitates access to other factors required to transcribe the IFN $\gamma$ gene. It will be of particular interest to determine whether T-bet is involved in the remodeling of the IFN $\gamma$ locus during Th1 differentiation.

\section{Summary}

The genetic programs that specify lineage commitment in the T helper cell are beginning to be elucidated (Fig. 6).

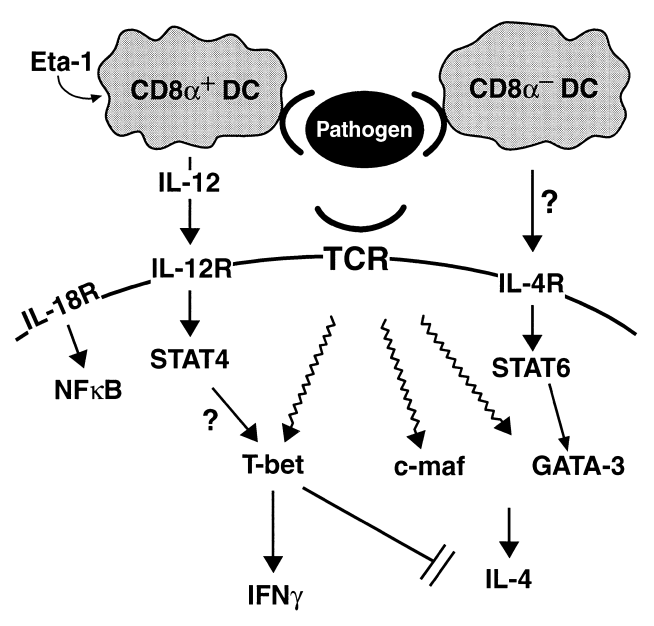

Figure 6. Overall schema of molecular basis of Th lineage commitment.

An attractive model to posit considers T-bet and GATA-3 as the master regulators of Th1 and Th2 differentiation, respectively, with c-Maf as the downstream factor that directly and selectively controls IL-4 gene transcription. The expression of T-bet and GATA-3 during $\mathrm{Th}$ differentiation are mirror images. T-bet and GATA-3 are strikingly similar in their ability to induce one lineage while simultaneously repressing the opposing lineage. T-bet may lie downstream of IL-12/Stat4 and IFN $\gamma$ (Stat1), the major inducers of Th1 differentiation, whereas GATA-3 is activated by IL-4/Stat6, the critical Th2-inducing cytokine. It is tempting to postulate that T-bet and GATA-3 regulate each other with T-bet suppressing GATA-3 expression during Th1 differentiation and GATA-3 inhibiting T-bet expression during Th2 development. Cytokine gene expression may more broadly reflect a balance between repressors and activators. Transcription factors such as T-bet that activate Th1 genetic programs repress Th2 programs (Szabo et al. 2000), whereas GATA-3 and c-Maf are activators in Th2 cells but play an opposing function as repressors in Th1 cells (Ho et al. 1998; Ouyang et al. 1998). Another example is the Stats. Although Stat4-deficient mice lack Th1 responses, mice lacking both Stat 4 and Stat6 mount a partial Th1 response suggesting that Stat6 may act as a repressor in Th1 cells (Kaplan et al. 1998). We would propose that the fate of a developing Th cell may be determined by the relative predominance of $\mathrm{T}$-bet and GATA-3 elicited by external signals such as pathogens, autoantigens, or allergens. Analysis of the regulatory regions of the T-bet, c-Maf, and GATA-3 genes themselves should yield prove informative in revealing the signaling pathways and molecules upstream of these three critically important transcription factors.

\section{References}

Abbas, A.K., Murphy, K.M., and Sher, A. 1996. Functional diversity of helper T lymphocytes [Review]. Nature 383: 787793. 
Abe, E., De Waal Malefyt, R., Matsuda, I., Arai, K.-I., and Arai, N. 1992. An 11-base-pair DNA sequence motif apparently unique to the human interleukin 4 gene confers responsiveness to T-cell activation signals. Proc. Natl. Acad. Sci. 89: 2864-2868.

Adachi, O., Kawai, T., Takeda, K., Matsumoto, M., Tsutsui, H., Sakagami, M., Nakanishi, K., and Akira, S. 1998. Targeted disruption of the $M y D 88$ gene results in loss of IL-1- and IL-18-mediated function. Immunity 9: 143-150.

Agarwal, S. and Rao, A. 1998a. Long-range transcriptional regulation of cytokine gene expression. Curr. Opin. Immunol. 10: 345-352.

. 1998b. Modulation of chromatin structure regulates cytokine gene expression during T-cell differentiation. Immunity 9: 765-775.

Agarwal, S., Viola, J.P.B., and Rao, A. 1999. Chromatin-based regulatory mechanisms governing cytokine gene transcription. J. Allergy Clin. Immunol. 103: 990-999.

Akiba, H., Miyahira, Y., Atsuta, M., Takeda, K., Nohara, C., Futagawa, T., Matsuda, H., Aoki, T., Yagita, H., and Okumura, K. 2000. Critical contribution of OX40 ligand to T helper cell type 2 differentiation in experimental Leishmaniasis. J. Exp. Med. 191: 375-380.

Aronica, M.A., Mora, A.L., Mitchell, D.B., Finn, P.W., Johnson, J.E., Sheller, J.R., and Boothby, M.R. 1999. Preferential role for NF-kB/Rel signaling in the type 1 but not type 2 T-celldependent immune response in vivo. J. Immunol. 163: 51165124.

Arthur, R.P. and Mason, D. 1986. T cells that help B cell responses to soluble antigen are distinguishable from those producing interleukin 2 on mitogenic or allogeneic stimulation. J. Exp. Med. 163: 774-786.

Ashkar, S., Weber, G.F., Panoutsakopoulou, V., Sanchirico, M.E., Jansson, M., Zawaideh, S., Rittling, S.R., Denhardt, D.T., Glimcher, M.J., and Cantor, H. 2000. Eta-1 (osteopontin): An early component of type-1 (cell-mediated) immunity. Science 287: 860-864.

Aune, T.M., Penix, L.A., Rincon, M.R., and Flavell, R.A. 1997. Differential transcription directed by discrete gamma interferon promoter elements in naive and memory (effector) CD4 T cells and CD8 T cells. Mol. Cell. Biol. 17: 199-208.

Bach, E.A., Szabo, S.J., Dighe, A.S., Ashkenazi, A., Aguet, M., Murphy, K.M., and Schreiber, R.D. 1995. Ligand-induced autoregulation of IFN- $\gamma$ receptor $\beta$ chain expression in T helper cell subsets. Science 270: 1215-1218.

Bamshad, M., Lin, R.C., Law, D.J., Watkins, W.C., Krakowiak, P.A., Moore, M.E., Franceschini, P., Lala, R., Holmes, L.B., Gebuhr, T.C. et al. 1997. Mutations in human TBX3 alter limb, apocrine and genital development in ulnar-mammary syndrome. Nat. Genet. 16: 311-315.

Barbulescu, K., Meyer zum Büschenfelde, K.H., and Neurath, M.F. 1997. Constitutive and inducible protein/DNA interactions of the interferon- $\gamma$ promoter in in vivo CD45RA and CD45RO T helper subsets. Eur. J. Immunol. 27: 1098-1107.

Barbulescu, K., Becker, C., Schlaak, J.F., Schmitt, E., Meyer zum Büschenfelde, K.-H., and Neurath, M.F. 1998. IL-12 and IL18 differentially regulate the transcriptional activity of the human IFN- $\gamma$ promoter in primary $\mathrm{CD}^{+} \mathrm{T}$ lymphocytes. $J$. Immunol. 160: 3642-3647.

Barner, M., Mohrs, M., Brombacher, F., and Kopf, M. 1998. Differences between IL-4R $\alpha$-deficient and IL-4-deficient mice reveal a role for IL-13 in the regulation of Th2 responses. Curr. Biol. 8: 669-672.

Basson, C.T., Bachinsky, D.R., Lin, R.C., Levi, T., Elkins, J.A., Soults, J., Grayzel, D., Kroumpouzou, E., Traill, T.A., Leblanc-Straceski, J. et al. 1997. Mutations in human cause limb and cardiac malformation in Holt-Oram syndrome. Nat. Genet. 15: 30-35.

Bhattacharya, S., Eckner, R., Grossman, S., Oldread, E., Arany, Z., D'Andrea, A., and Livingston, D.M. 1996. Cooperation of Stat2 and p300/CBP in signalling induced by interferon- $\alpha$. Nature 383: 344-347.

Bird, J.J., Brown, D.R., Mullen, A.C., Moskowitz, N.H., Mahowald, M.A., Sider, J.R., Gajewski, T.F., Wang, C.-R., and Reiner, S.L. 1998. Helper T cell differentiation is controlled by the cell cycle. Immunity 9: 229-237.

Bix, M. and Locksley, R.M. 1998. Independent and epigenetic regulation of the interleukin-4 alleles in CD4+ T cells. Science 281: 1352-1354.

Bonecchi, R., Bianchi, G., Bordignon, P.P., D'Ambrosio, D., Lang, R., Borsatti, A., Sozzani, S., Allavena, P., Gray, P., Mantovani, A., and Sinigaglia, F. 1998. Differential expression of chemokine receptors and chemotactic responsiveness of type $1 \mathrm{~T}$ helper cells (Th1s) and Th2s. J. Exp. Med. 187: 129-134.

Borges, E., Tietz, W., Steegmaier, M., Moll, T., Hallmann, R., Hamann, A., and Vestweber, D. 1997. P-selectin glycoprotein ligand-1 (PSGL-1) on T helper 1 but not on $\mathrm{T}$ helper 2 cells binds to P-selectin and supports migration into in flamed skin. J. Exp. Med. 185: 573-578.

Brinkmann, V., Geiger, T., Alkan, S., and Heusser, C.H. 1993. Interferon alpha increases the frequency of interferon gamma-producing human CD4+ T cells. I. Exp. Med. 178: $1655-1663$.

Brombacher, F., Schäfer, T., Weissenstein, U., Tschopp, C., Andersen, E., Bürki, K., and Baumann, G. 1994. IL-2 promoter-driven lacZ expression as a monitoring tool for IL-2 expression in primary $\mathrm{T}$ cells of transgenic mice. Int. Immunol. 6: 189-197.

Brown, J.A., Titus, R.G., Nabavi, N., and Glimcher, L.H. 1996. Blockade of CD86 ameliorates Leishmania major infection by downregulating the Th2 response. I. Invest. Dermatol. 174: $1303-1308$.

Brown, M.A. and Hural, J. 1997. Functions of IL-4 and control of its expression. Crit. Rev. Immunol. 17: 1-32.

Bruhn, K.W., Nelms, K., Boulay, J.-L., Paul, W.E., and Lenardo, M.J. 1993. Molecular dissection of the mouse interleukin-4 promoter. Proc. Nat1. Acad. Sci. 90: 9707-9711.

Bulfone, A., Smiga, S.M., Shimamura, K., Peterson, A., Puelles, L., and Rubenstein, J.L.R. 1995. T-Brain-1: A homolog of Brachyury whose expression defines molecularly distinct domains within the cerebral cortex. Neuron 15: 63-78.

Campbell, P.M., Pimm, J., Ramassar, V., and Halloran, P.F. 1996. Identification of a calcium-inducible, cyclosporine sensitive element in the IFN-gamma promoter that is a potential NFAT binding site. Transplantation 61: 933.

Carter, L.L. and Murphy, K.M. 1999. Lineage-specific requirement for signal transducer and activator of transcription (Stat)4 in interferon $\gamma$ production from CD4+ versus CD8+ T cells. J. Exp. Med. 189: 1355-1360.

Cerretti, D.P., Kozlosky, C.J., Mosley, B., Nelson, N., Van, N.N., Greenstreet, T.A., March, C.J., Kronheim, S.R., Druck, T., Cannizzaro, L.A. et al. 1992. Molecular cloning of the interleukin-1 $\beta$ converting enzyme. Science 256: 97-100.

Chuvpilo, S., Schomberg, C., Gerwig, R., Heinfling, A., Reeves, R., Grummt, F., and Serfling, E. 1993. Multiple closelylinked NFAT/octamer and HMG I (Y) binding sites are part of the interleukin-4 promoter. Nucleic Acids Res. 21: 5694 5704.

Coccia, E.M., Passini, N., Battistini, A., Pini, C., Sinigaglia, F., and Rogge, L. 1999. Interleukin-12 induces expression of interferon regulatory factor-1 via signal transducer and activa- 
tor of transcription-4 in human T helper type 1 cells. J. Biol. Chem. 274: 6698-6703.

Cockerill, P.N., Bert, A.G., Jenkins, F., Ryan, G.R., Shannon, M.F., and Vadas, M.A. 1995. Human granulocyte-macrophage colony-stimulating factor enhancer function is associated with cooperative interactions between AP-1 and NFATp/c. Mol. Cell. Biol. 15: 2071-2079.

Coffman, R.L. and Reiner, S.L. 1999. Instruction, selection, or tampering with the odds? Science 284: 1283.

Coffman, R.L., Mocci, S., and O'Garra, A. 1999. The stability and reversibility of Th1 and Th2 populations. Curr. Top. Microbiol. Immunol. 238: 1-12.

Cohn, L., Tepper, J.S., and Bottomly, K. 1998. IL-4-independent induction of airway hyperresponsiveness by Th2, but not Th1, cells. J. Immunol. 161: 3813-3816.

Constant, S. and Bottomly, K. 1997. Induction of Th1 and Th2 $\mathrm{CD}^{+} \mathrm{T}$ cell responses: The alternative approaches. Annu. Rev. Immunol. 15: 297-322.

Coyle, A.J., Lloyd, C., Tian, J., Nguyen, T., Erikkson, C., Wang, L., Ottoson, P., Persson, P., Delaney, T., Lehar, S. et al. 1999. Crucial role of the interleukin 1 receptor family member $\mathrm{T} 1 / \mathrm{ST} 2$ in $\mathrm{T}$ helper cell type 2-mediated lung mucosal immune responses. J. Exp. Med. 190: 895-902.

Crabtree, G. 1989. Contingent genetic regulatory events in $\mathrm{T}$ lymphocyte activation. Science 249: 355-360.

D'Ambrosio, D.D., Iellem, A., Bonecchi, R., Mazzeo, D., Sozzani, S., Mantovani, A., and Sinigaglia, F. 1998. Selective up-regulation of chemokine receptors CCR4 and CCR8 upon activation of polarized human type 2 Th cells. I. Immunol. 161: 5111-5115.

Davis, M.M., Chien, Y.H., Gascoigne, N.R.J., and Hedrick, S.M. 1984. A murine $\mathrm{T}$ cell receptor gene complex: Isolation, structure and rearrangement. Immunol. Rev. 81: 235-258.

Dent, A.L., Shaffer, A.L., Yu, X., Allman, D., and Staudt, L.M. 1997. Control of inflammation, cytokine expression, and germinal center formation by BCL-6. Science 276: 589-592.

Dent, A.L., Hu-Li, J., Paul, W.E., and Staudt, L.M. 1998. T helper type 2 inflammatory disease in the absence of interleukin 4 and transcription factor STAT6. Proc. Natl. Acad. Sci. 95: 13823-13828.

Dong, C., Yang, D.D., Wysk, M., Whitmarsh, A.J., Davis, R.J., and Flavell, R.A. 1998. Defective T cell differentiation in the absence of Ink1. Science 282: 2092-2095.

Dong, H., Zhu, G., Tamada, K., and Chen, L. 1999. B7-H1, a third member of the B7 family, co-stimulates T-cell proliferation and interleukin-10 secretion. Nat. Med. 12: 13651369.

Durand, D., Shaw, J., Bush, M., Replogle, R., Belagaje, R., and Crabtree, G. 1988. Characterization of antigen receptor response elements within the interleukin-2 enhancer. Mol. Cell. Biol. 8: 1715-1724.

Emmel, E.A., Verweij, C.L., Durand, D.B., Higgins, K.M., Lacy, E., and Crabtree, G.R. 1989. Cyclosporin A specifically inhibits function of nuclear proteins involved in T cell activation. Science 246: 1617-1620.

Emson, C.L., Bell, S.E., Jones, A., Wisden, W., McKenzie, A.N.J., and de Vries, J.E. 1998. Interleukin (IL)-4-independent induction of immunoglobulin (Ig)E, and perturbation of T cell development in transgenic mice expressing IL-13. J. Exp. Med. 188: 399-404.

Ernst, P. and Smale, S.T. 1995. Combinatorial regulation of transcription I: General aspects of transcriptional control. Immunity 2: 311-319.

Fantuzzi, G., Puren, A.J., Harding, M.W., Livingston, D.J., and Dinarello, C.A. 1998. Interleukin-18 regulation of interferon gamma production and cell proliferation as shown in inter- leukin-1 $\beta$-converting enzyme (caspase-1)-deficient mice. Blood 91: 2118-2125.

Finkelman, F.D., Morris, S.C., Orekhova, T., Mori, M., Donaldson, D., Reilly, N.L., Schopf, L., and Urban J.F. Jr. 2000. Stat6 regulation of in vivo IL-4 responses. I. Immunol.164: 23032310.

Fitzpatrick, D.R., Shirley, K.M., and Kelso, A. 1999. Stable epigenetic inheritance of regional IFN-gamma promoter demethylation in CD44 ${ }^{\text {high }}$ CD8+ T lymphocytes. I. Immunol. 162: 5053-5057.

Freeman, G.J., Borriello, F., Hodes, R.J., Reiser, H., Hathcock, K.S., Laszlo, G., McKnight, A.J., Kim, J., Du, L., Lombard, D.B. et al. 1993. Uncovering of functional alternative CTLA-4 counter-receptor in B7-deficient mice. Science 262: 907-909.

Gett, A.V. and Hodgkin, P.D. 1998. Cell division regulates the T cell cytokine repertoire, revealing a mechanism underlying immune class regulation. Proc. Nat1. Acad. Sci. 95: 94889493.

Ghayur, T., Banerjee, S., Hugunin, M., Butler, D., Herzog, L., Carter, A., Quintal, L., Sekut, L., Talanian, R., Paskind, M. et al. 1997. Caspase-1 processes IFN-gamma-inducing factor and regulates LPS-induced IFN-gamma production. Nature 386: 619-623.

Glimcher, L.H. and Singh, H. 1999. Transcription factors in lymphocyte development-T and B cells get together. Cell 96: $13-23$.

Glimcher, L.H., Ranger, A.M., and Ho, I.-C. 1999. Lineage commitment of $\mathrm{CD}^{+} \mathrm{T}$ helper lymphocytes. In Hematopoiesis (ed. L. Zon), In press. Oxford University Press, New York.

Goldfeld, A.E., McCaffrey, P.G., Strominger, J.L., and Rao, A. 1993. Identification of a novel cyclosporin-sensitive element in the human tumor necrosis factor $\alpha$ gene promoter. J. Exp. Med. 178: 1365-1379.

Grakoui, A., Donermeyer, D.L., Kanagawa, O., Murphy, K.M., and Allen, P.M. 1999. TCR-independent pathways mediate the effects of antigen dose and altered peptide ligands on Th cell polarization. J. Immunol. 162: 1923-1930.

Green, J.M., Noel, P.J., Sperling, A.I., Walunas, T.L., Gray, G.S., Bluestone, J.A., and Thompson, C.B. 1994. Absence of B7dependent responses in CD28-deficient mice. Immunity 1: 501-508.

Gu, L., Tseng, S., Horner, R.M., Tam, C., Loda, M., and Rollins, B.J. 2000. Control of Th2 polarization by the chemokine monocyte chemoattractant protein-1. Nature 404: 407-411.

Gu, Y., Kuida, K., Tsutsui, H., Ku, G., Hsiao, K., Fleming, M.A., Hayashi, N., Higashino, K., Okamura, H., Nakanishi, K. et al. 1997. Activation of interferon- $\gamma$ inducing factor mediated by interleukin-1 $\beta$ converting enzyme. Science 275: 206-209.

Hendriks, R.W., Nawijn, M.C., Engel, J.D., VanDoorninck, H., Grosveld, F., and Karis, A. 1999. Expression of the transcription factor GATA-3 is required for the development of the earliest $\mathrm{T}$ cell progenitors and correlates with stages of cellular proliferation in the thymus. Eur. J. Immunol. 29: 19121918.

Herrmann, B.G., Labeit, S., Poustka, A., King, T.R., and Lehrach, H. 1990. Cloning of the $T$ gene required in mesoderm formation in the mouse. Nature 343: 617-622.

Himes, S.R., Coles, L.S., Reeves, R., and Shannon, M.F. 1996. High mobility group protein $\mathrm{I}(\mathrm{Y})$ is required for function and for c-Rel binding to CD28 response elements within the GM-CSF and IL-2 promoters. Immunity 5: 479-489.

Ho, I.-C., Vorhees, P., Marin, N., Oakley, B.K., Tsai, S.F., Orkin, S.H., and Leiden, J.M. 1991. Human GATA-3: A lineagerestricted transcription factor that regulates the expression of the T cell receptor alpha gene. EMBO I. 10: 1187-1192. 
Ho, I.-C., Hodge, M.R., Rooney, J.W., and Glimcher, L.H. 1996. The proto-oncogene c-maf is responsible for tissue-specific expression of interleukin-4. Cell 85: 973-983.

Ho, I.-C., Lo, D., and Glimcher, L.H. 1998. C-maf promotes Th2 and attenuates Th1 differentiation by both IL-4 dependent and independent mechanisms. J. Exp. Med. 188:(10) 18591866.

Ho, I.-C., Kaplan, M.H., Jackson-Grusby, L., Glimcher, L.H., and Grusby, M.J. 1999. Marking interleukin-4 producing cells by knock-in of the interleukin-4 gene. Int. Immunol. 11: 101105.

Hodge, M.J., Rooney, J.W., and Glimcher, L.H. 1995. The proximal promoter of the IL-4 gene is composed of multiple essential regulatory sites which bind at least two distinct factors. J. Immunol. 154: 6397-6405.

Hodge, M.R., Chun, H.J., Rengarajan, J., Alt, A., Lieberson, R., and Glimcher, L.H. 1996a. NFAT-driven interleukin-4 transcription potentiated by NIP45. Science 274: 1903-1905.

Hodge, M.R., Ranger, A.M., Charles de la Brousse, F., Hoey, T., Grusby, M.J., and Glimcher, L.H. 1996b. Hyperproliferation and dysregulation of IL-4 expression in NF-ATp-deficient mice. Immunity 4: 1-20.

Hoey, T. and Grusby, M.J. 1999. STATs as mediators of cytokine-induced responses. Adv. Immunol. 71: 145-162.

Hoey, T., Sun, Y.-L., Williamson, K., and Xu, X. 1995. Isolation of two new members of the NF-AT gene family and functional characterization of the NF-AT proteins. Immunity 2: 461-472.

Hollander, G.A., Zuklys, S., Morel, C., Mizoguchi, E., Mobisson, K., Simpson, S., Terhorst, C., Wishart, W., Golan, D.E., Bhan, A.K., and Burakoff, S.J. 1998. Monoallelic expression of the interleukin-2 locus. Science 279: 2118-2121.

Hoshino, K., Kashiwamura, S.I., Kuribayashi, K., Kodama, T., Tsujimura, T., Nakanishi, K., Matsuyama, T., Takeda, K., and Akira, S. 1999. The absence of interleukin 1 receptorrelated T1/ST2 does not affect T helper cell type 2 development and its effector function. J. Exp. Med. 190: 1541-1547.

Hsieh, C.-S., Macatonia, S.E., Tripp, C.S., Wolf, S.F., O'Garra, A., and Murphy, K.M. 1993. Development of TH1 CD4 ${ }^{+}$T cells through IL-12 produced by Listeria-induced macrophages. Science 260: 547-549.

Huang, H., Hu-Li, J., Chen, H., Ben-Sasson, S.Z., and Paul, W.E. 1997. IL-4 and IL-13 production in differentiated T helper type 2 cells is not IL-4 dependent. J. Immunol. 159:37313738.

Hutloff, A., Dittrich, A.M., Beier, K.C., Eljaschewitsch, B., Kraft, R., Anagnostopoulos, I., and Kroczek, R.A. 1999. ICOS is an inducible T-cell co-stimulator structurally and functionally related to CD28. Nature 397: 263-266.

Jacobson, N.G., Szabo, S.J., Weber-Nordt, R.M., Zhong, Z., Schreiber, R.D., Darnell, J.E., and Murphy, K.M. 1995. Interleukin 12 signaling in $\mathrm{T}$ helper type 1 (Th1) cells involves tyrosine phosphorylation of signal transducer and activator of transcription (Stat)3 and Stat4. I. Exp. Med. 181: 17551762.

Jain, J., Loh, C., and Rao, A. 1995. Transcriptional regulation of the IL-2 gene. Curr. Biol. 7: 333-342.

Jankovic, D., Kullberg, M.C., Noben-Trauth, N., Caspar, P., Paul, W.E., and Sher, A. 2000. Single cell analysis reveals that IL-4 receptor/Stat6 signaling is not required for the in vivo or in vitro development of CD4+ lymphocytes with a Th2 cytokine profile. J. Immunol. 164: 3047-3055.

Kadonaga, J.T. 1998. Eukaryotic transcription: An interlaced network of transcription factors and chromatin-modifying machines. Cell 92: 307-313

Kamogawa, Y., Minasi, L.E., Carding, S.R., Bottomly, K., and
Flavell, R.A. 1993. The relationship of IL-4- and IFN $\gamma$-producing $\mathrm{T}$ cells studied by lineage ablation of IL-4-producing cells. Cell 75: 985-995.

Kanakaraj, P., Ngo, K., Wu, Y., Angulo, A., Ghazal, P., Harris, C.A., Siekierka, J.J., Peterson, P.A., and Fung-Leung, W.P. 1999. Defective interleukin (IL)-18-mediated natural killer and $\mathrm{T}$ helper cell type 1 responses in IL-1 receptor-associated kinase (IRAK)-deficient mice. J. Exp. Med. 189: 1129-1138.

Kaplan, M.H., Sun, Y.L., Hoey, T., and Grusby, M.J. 1996a. Impaired IL-12 responses and enhanced development of Th2 cells in Stat4-deficient mice. Nature 382: 174-177.

Kaplan, M.H., Schindler, U., Smiley, S.T., and Grusby, M.J. 1996b. Stat6 is required for mediating responses to IL-4 and for the development of Th2 cells. Immunity 4: 313-319.

Kaplan, M.H., Wurster, A.L., and Grusby, M.J. 1998. A signal transducer and activator of transcription (Stat)4-independent pathway for the development of T helper type 1 cells. J. Exp. Med. 188: 1191-1196.

Kaplan, M.H., Wurster, A.L., Smiley, S.T., and Grusby, M.J. 1999. Stat6-dependent and -independent pathways for IL-4 production. J. Immunol. 163: 6536-6540.

Kiani, A., Viola, J.P.B., Lichtman, A.H., and Rao, A. 1997. Down-regulation of IL-4 gene transcription and control of Th2 cell differentiation by a mechanism involving NFAT1. Immunity 7: 849-860.

Kim, J., Ho, I.C., Grusby, M., and Glimcher, L.H. 1999. The transcription factor c-Maf controls the production of IL-4 but not other Th2 cytokines. Immunity 10: 745-751.

Kohno, K., Kataoka, J., Ohtsuki, T., Suemoto, Y., Okamoto, I., Usui, M., Ikeda, M., and Kurimoto, M. 1997. IFN-gammainducing factor (IGIF) is a costimulatory factor on the activation of Th1 but not Th2 cells and exerts its effect independently of IL-12. J. Immunol. 158: 1541-1550.

Kojima, H., Takeuchi, M., Ohta, T., Nishida, Y., Arai, N., Ikeda, M., Ikegami, H., and Kurimoto, M. 1998. Interleukin-18 activates the IRAK-TRAF6 pathway in mouse EL-4 cells. Biochem. Biophys. Res. Commun. 244: 183-186.

Kopf, M., Le Gros, G., Bachmann, M., Lamers, M.C., Bluethmann, H., and Kohler, G. 1993. Disruption of the murine IL-4 gene blocks Th2 cytokine responses. Nature 362: 245248.

Korzus, E., Torchia, J., Rose, D.W., Xu, L., Kurokawa, R., McInerney, E.M., Mullen, T.M., Glass, C.K., and Rosenfeld, M.G. 1998. Transcription factor-specific requirements for coactivators and their acetyltransferase functions. Science 279: 703-707.

Kubo, M., Kincaid, R.L., Webb, D.R., and Ransom, J.T. 1994a. The $\mathrm{Ca}^{2+} /$ calmodulin-activated, phosphoprotein phosphatase calcineurin is sufficient for positive transcriptional regulation of the mouse IL-4 gene. Int. Immunol. 6: 179-188.

Kubo, M., Kincaid, R.L., and Ransom, J.T. 1994b. Activation of the interleukin-4 gene is controlled by the unique calcineurin-dependent transcriptional factor $\mathrm{NF}(\mathrm{P})$. J. Biol. Chem. 269: 19441-19446.

Kuchroo, V.K., Das, M.P., Brown, J.A., Ranger, A.M., Zamvil, S.S., Sobel, R.A., Nabavi, N., and Glimcher, L.H. 1995. B7-1 and B7-2 costimulatory molecules activate differentially the Th1/Th2 developmental pathways: Application to autoimmune disease therapy. Cell 80: 707-718.

Kuhn, R., Rajewsky, K., and Muller, W. 1991. Generation and analysis of interleukin-4 deficient mice. Science 254: 707710.

Kurata, H., Lee, H.J., O'Garra, A., and Arai, N. 1999. Ectopic expression of activated Stat 6 induces the expression of Th2 specific cytokines and transcription factors in developing Th1 cells. Immunity 11: 677-688. 
Lane, P. 2000. Role of OX40 signals in coordinating CD4 T cell selection, migration, and cytokine differentiation in $\mathrm{T}$ helper (Th) 1 and Th2 cells. J. Exp. Med. 191: 201-205.

Lederer, J.A., Liou, J.S., Todd, M.D., Glimcher, L.H., and Lichtman, A.H. 1994. Regulation of cytokine gene expression in $\mathrm{T}$ helper cell subsets. J. Immunol. 152: 77-86.

Lederer, J.A., Perez, V.L., DesRoches, L., Kim, S.M., Abbas, A.K., and Lichtman, A.H. 1996. Cytokine transcriptional events during helper $\mathrm{T}$ cell subset differentiation. J. Exp. Med. 184: 397-406.

Lee, H.J., O'Garra, A., Arai, K.I., and Arai, N. 1998. Characterization of cis-regulatory elements and nuclear factors conferring Th2-specific expression of the IL-5 gene: A role for a GATA-binding protein. I. Immunol. 160: 2343-2352.

Lenschow, D.J., Walunas, T.L., and Bluestone, J.A. 1996. CD28/ $\mathrm{B} 7$ system of $\mathrm{T}$ cell costimulation. Annu. Rev. Immunol. 14: 233.

Li, B., Tournier, C., Davis, R.J., and Flavell, R.A. 1999. Regulation of IL-4 expression by the transcription factor JunB during $\mathrm{T}$ helper cell differentiation. EMBO J. 18: 420-432.

Li, Q.Y., Newbury-Ecob, R.A., Terrett, J.A., Wilson, D.I., Curtis, A.R.J., Yi, C.H., Gebuhr, T., Bullen, P.J., Robson, S.C., Strachan, T. et al. 1997. Holt-Oram syndrome is caused by mutations in TBX5, a member of the Brachyury $(T)$ gene family. Nat. Genet. 15: 21-29.

Lichtman, A.H., Chin, J., Schmidt, J.A., and Abbas, A.K. 1988. Role of interleukin 1 in the activation of $\mathrm{T}$ lymphocytes. Proc. Nat1. Acad. Sci. 85: 9699-9703.

Linehan, L.A., Warren, W.D., Thompson, P.A., Grusby, M.J., and Berton, M.T. 1998. STAT6 is required for IL-4-induced germline Ig gene transcription and switch recombination. J. Immunol. 161: 302-310.

Ling, V., Wu, P.W., Finnerty, H.F., Bean, K.M., Spaulding, V., Fouser, L.A., Leonard, J.P., Hunter, S.E., Zollner, R., Thomas, J.L. et al. 2000. Identification of GL50, a novel B7-like protein that functionally binds to ICOS receptor. I. Immunol. 164: 1653-1657.

Lohning, M., Stroehmann, A., Coyle, A.J., Grogan, J.L., Lin, S., Gutierrez-Ramos, J.C., Levinson, D., Radbruch, A., and Kamradt, T. 1998. T1/ST2 is preferentially expressed on murine Th2 cells, independent of interleukin 4, interleukin 5, and interleukin 10, and important for Th2 effector function. Proc. Natl. Acad. Sci. 95: 6930-6935.

Lohoff, M., Ferrick, D., Mittrucker, H.W., Duncan, G.S., Bischof, S., Rollinghoff, M., and Mak, T.W. 1997. Interferon regulatory factor- 1 is required for a $\mathrm{T}$ helper 1 immune response in vivo. Immunity 6: 681-689.

Lu, H.T., Yang, D.D., Wysk, M., Gatti, E., Mellman, I., Davis, R.J., and Flavell, R.A. 1999. Defective IL-12 production in mitogen-activated protein (MAP) kinase kinase 3 (Mkk3)deficient mice. EMBO J. 18: 1845-1857.

Luo, C., Burgeon, E., and Rao, A. 1996. Mechanisms of transactivation by nuclear factor of activated T cells-1. J. Exp. Med. 184: 141-147.

Macatonia, S.E., Hsieh, C., Murphy, K.M., and O'Garra, A. 1993. Dendritic cells and macrophages are required for Th1 development of $\mathrm{CD}^{+} \mathrm{T}$ cells for $\alpha \beta$-TCR transgenic mice: IL-12 can substitute for macrophages to stimulate IFN- $\gamma$ production. Int. Immunol. 5: 1119.

Maggi, E., Parronchi, P., Manetti, R., Simonelli, C., Piccinni, M.P., Rugiu, F.S., DeCarli, M., Ricci, M., and Romagnani, S 1992. Reciprocal regulatory effects of IFN-gamma and IL-4 on the in vitro development of human Th1 and Th2 clones. J. Immunol. 148: 2142.

Maggirwar, S.B., Harhaj, E.W., and Sun, S.C. 1997. Regulation of the interleukin-2 CD28-responsive element by NF-ATp and various NF-кB/Rel transcription factors. Mol. Cell. Biol. 17: 2605-2614.

Magram, J., Connaughton, S.E., Warrier, R.R., Carvajal, D.M., Wu, C., Ferrante, J., Stewart, C., Sarmiento, U., Faherty, D.A., and Gately, M.K. 1996. IL-12-deficient mice are defective in IFN $\gamma$ production and type 1 cytokine responses. Immunity 4: 471-481.

Maldonado-Lopez, R., DeSmedt, T., Michel, P., Godfroid, J., Pajak, B., Heirman, C., Thielemans, K., Leo, O., Urbain, J., and Moser, M. 1999. CD8 $\alpha+$ and CD $8 \alpha-$ subclasses of dendritic cells direct the development of distinct $\mathrm{T}$ helper cells in vivo. J. Exp. Med. 189: 587-592.

Manetti, R., Parronchi, P., Giudizi, M.G., Piccinni, M.-P., Maggi, E., Trinchieri, G., and Romagnani, S. 1993. Natural killer cell stimulatory factor (interleukin 12 [IL-12]) induces T helper type 1 (Th1)-specific immune responses and inhibits the development of IL-4-producing Th cells. J. Exp. Med. 177: 1199 .

Marx, J. 1993. Two major signal pathways linked. Science 262: 988-989.

Masuda, E.S., Tokumitsu, H., Tsuboi, A., Shlomai, J., Hung, P., Arai, K.-I., and Arai, N. 1993. The granulocyte-macrophage colony-stimulating factor promoter cis-acting element CLEO mediates induction signals in $\mathrm{T}$ cells and is recognized by factors related to AP1 and NFAT. Mol. Cell. Biol. 13: 73997407.

Masuda, E.S., Naito, Y., Tokumitsu, H., Campbell, D., Saito, F., Hannum, C., Arai, K.-I., and Arai, N. 1995. NFATx, a novel member of the nuclear factor of activated $\mathrm{T}$ cells family that is expressed predominantly in the thymus. Mol. Cell. Biol. 15: 2697-2706.

Matsumoto, S., Tsuji-Takayama, K., Aizawa, K., Koide, K., Takeuchi, M., Ohta, T., and Kurimoto, M. 1997. Interleukin18 activates NF-kappaB in murine T helper type 1 cells. Biochem. Biophys. Res. Commun. 234: 454-457.

McCaffrey, P.G., Luo, C., Kerppola, T.K., Jain, J., Badalian, T.M., Ho, A.M., Burgeon, E., Lane, W.S., Lambert, J.N., Curran, T. et al. 1993. Isolation of the cyclosporin-sensitive T cell transcription factor NFATp. Science 262: 750-754.

McKenzie, G.J., Emson, C.L., Bell, S.E., Anderson, S., Fallon, P., Zurawski, G., Murray, R., Grencis, R., and McKenzie, A.N.J. 1998. Impaired development of Th2 cells in IL-13-deficient mice. Immunity 9: 423-432.

Meisler, M.H. 1997. Mutation watch: Mouse brachyury $(T)$, the T-box gene family, and human disease. Mamm. Gen. 8: 799800.

Meraz, M.A., White, J.M., Sheehan, K.C., Bach, E.A., Rodig, S.J., Dighe, A.S., Kaplan, D.H., Riley, J.K., Greenlund, A.C., Campbell, D. et al. 1996. Targeted disruption of the Stat1 gene in mice reveals unexpected physiologic specificity in the JAK-STAT signaling pathway. Cell 84: 431-442.

Micallef, M.J., Ohtsuki, T., Kohno, K., Tanabe, F., Ushio, S., Namba, M., Tanimoto, T., Torigoe, K., Fujii, M., Ikeda, M. et al. 1996. Interferon-gamma-inducing factor enhances $\mathrm{T}$ helper 1 cytokine production by stimulated human $\mathrm{T}$ cells: Synergism with interleukin-2 for interferon-gamma production. Eur. J. Immunol. 26: 1647-1651.

Minasi, L.E., Kamogawa, Y., Carding, S., Bottomly, K., and Flavell, R.A. 1993. The selective ablation of interleukin 2-producing cells isolated from transgenic mice. J. Exp. Med. 177: 1451-1459.

Minty, A., Chalon, P., Derocq, J.-M., Dumont, X., Guillemot, J.-C., Kaghad, M., Labit, C., Leplatois, P., Liauzun, P., Miloux, B. et al. 1993. Interleukin-13 is a new human lymphokine regulating inflammatory and immune responses. Nature 362: 248-250. 
Miyatake, S., Shlomai, J., Arai, K., and Arai, N. 1991. Characterization of the mouse granulocyte-macrophage colonystimulating factor (GM-CSF) gene promoter: Nuclear factors that interact with an element shared by three lymphokine genes-Those for GM-CSF, interleukin-4 (IL-4), and IL-5. Mol. Cell. Biol. 11: 5894-5901.

Mocci, S. and Coffman, R.L. 1995. Induction of a Th2 population from a polarized Leishmania-specific Th1 population by in vitro culture with IL-4. J. Immunol. 154: 3779-3787.

1997. The mechanism of in vitro T helper cell type 1 to $\mathrm{T}$ helper cell type 2 switching in highly polarized Leishmania major-specific $\mathrm{T}$ cell populations. I. Immunol. 158: 1559-1564.

Mosmann, T.R. and Coffman, R.L. 1989. TH1 and TH2 cells: Different patterns of lymphokine secretion lead to different functional properties. Annu. Rev. Immunol. 7: 145-173.

Mosmann, T.R., Cherwinski, H., Bond, M.W., Giedlin, M.A., and Coffman, R.L. 1986. Two types of murine helper T cell clone. I. Definition according to profiles of lymphokine activities and secreted proteins. J. Immunol. 136: 2348-2357.

Murata, T., Ishii, N., Takano, H., Miura, S., Ndhlovu, S., Nose, M., Noda, T., and Sugamura, K. 2000. Impairment of antigen-presenting cell function in mice lacking expression of OX40 ligand. J. Exp. Med. 1991: 365-374.

Murphy, E., Shibuya, K., Hosken, N., Openshaw, P., Maino, V., Davis, K., Murphy, K., and O'Garra, A. 1996. Reversibility of $\mathrm{T}$ helper 1 and 2 populations is lost after long-term stimulation. J. Exp. Med. 183: 901-913.

Nakajima, A., Watanabe, N., Yoshino, S., Yagita, H., Okumura, K., and Azuma, M. 1997. Requirement of CD28-CD86 costimulation in the interaction between antigen-primed $\mathrm{T}$ helper type 2 and B cells. Int. Immunol. 9: 637-644.

Nakamura, T., Kamogawa, Y., Bottomly, K., and Flavell, R.A. 1997. Polarization of IL-4- and IFN- $\gamma$-producing CD4 ${ }^{+} \mathrm{T}$ cells following activation of naive $\mathrm{CD}^{+}{ }^{+} \mathrm{T}$ cells. J. Immunol. 158: 1085-1094.

Naramura, M., Hu, R.J., and Gu, H. 1998. Mice with a fluorescent marker for interleukin 2 gene activation. Immunity 9: $209-216$

Noben-Trauth, N., Shultz, L.D., Brombacher, F., Urban, J.F.J., $\mathrm{Gu}, \mathrm{H}$. , and Paul, W.E. 1997. An interleukin 4 (IL-4) independent pathway for CD4+ T cell IL-4 production is revealed in IL-4 receptor-deficient mice. Proc. Natl. Acad. Sci. 94: $10838-10843$.

Northrop, J.P., Ho, S.N., Chen, L., Thomas, D.J., Timmerman, L.A., Nolan, G.P., Admon, A., and Crabtree, G.R. 1994. NFAT components define a family of transcription factors targeted in T-cell activation. Nature 369: 497-502.

O'Garra, A. 1998. Cytokines induce the development of functionally heterogeneous $\mathrm{T}$ helper cell subsets. Immunity 8: $275-283$.

Okamura, H., Tsutsui, H., Komatsu, T., Yutsudo, M., Hakura, A., Tanimoto, T., Torigoe, K., Okura, T., Nukada, Y., Hattori, K. et al. 1995. Cloning of a new cytokine that induces IFN- $\gamma$ production by T cells. Science 378: 88-91.

Oukka, M., Ho, I.-C., Charles de la Brousse, F., Hoey, T., Grusby, M.J., and Glimcher, L.H. 1998. The transcription factor NFAT4 is involved in the generation and survival of T cells. Immunity 9: 295-304.

Ouyang, W., Ranganath, S.H., Weindel, K., Bhattacharya, D., Murphy, T.L., Sha, W.C., and Murphy, K.M. 1998. Inhibition of Th1 developmental mediated by GATA-3 through an IL-4 independent mechanism. Immunity 9: 745-755.

Ouyang, W., Jacobson, N.G., Bhattacharya, D., Gorham, J.D., Fenoglio, D., Sha, W.C., Murphy, T.L., and Murphy, K.M. 1999. The Ets transcription factor ERM is Th1-specific and induced by IL-12 through a Stat4-dependent pathway. Proc. Natl. Acad. Sci. 96: 3888-3893.

Ouyang, W., Lohning, M., Gao, Z., Assenmacher, M., Ranganath, S., Radbruch, A., and Murphy, K.M. 2000. Stat6-independent GATA-3 autoactivation directs IL-4-independent Th2 development and commitment. Immunity 12: 27-37.

Paliard, X., de Waal Malefizt, R., Yssel, H., Blanchard, D., Chretien, I., Abrams, J., de Vries, J., and Spits, H. 1988. Simultaneous production of IL-2, IL-4, and IFN-gamma by activated human $\mathrm{CD}^{+}$and $\mathrm{CD}^{+} \mathrm{T}$ cell clones. J. Immunol. 141: 849855.

Pandolfi, P.P., Roth, M.E., Karis, A., Leonard, M.W., Dzierzak, E., Grosveld, F.G., Engel, J.D., and Lindenbaum, M.H. 1995. Targeted disruption of the GATA3 gene causes severe abnormalities in the nervous system and in fetal liver haematopoiesis. Nat. Genet. 11: 40-44.

Papaioannou, V.E. 1997. T-box family reunion. Trends Genet. 13: $212-213$.

Parronchi, P., DeCarli, M., Manetti, R., Simonelli, C., Sampognaro, S., Piccinni, M.P., Macchia, D., Maggi, E., Del Prete, G., and Romagnani, S. 1992. IL-4 and IFN (alpha and gamma) exert opposite regulatory effects on the development of cytolytic potential by Th1 or Th2 human T cell clones. J. Immunol. 149: 2977.

Paul, W.E. and Seder, R.A. 1994. Lymphocyte responses and cytokines. Cell 76: 241-251.

Penix, L., Weaver, W.M., Pang, Y., Young, H.A., and Wilson, C.B. 1993. Two essential regulatory elements in the human interferon $\gamma$ promoter confer activation specific expression in T cells. J. Exp. Med. 178: 1483-1496.

Penix, L.A., Sweetser, M.T., Weaver, W.M., Hoeffler, J.P., Kerppola, T.K., and Wilson, C.B. 1996. The proximal regulatory element of the interferon- $\gamma$ promoter mediates selective expression in T cells. J. Biol. Chem. 271: 31964-31972.

Powrie, F. and Coffman, R.L. 1993. Cytokine regulation of Tcell function: Potential for therapeutic intervention. Immunol. Today 14: 270-274.

Pulendran, B., Smith, J.L., Caspary, G., Brasel, K., Pettit, D., Maraskovsky, E., and Maliszewski, C.R. 1999. Distinct dendritic cell subsets differentially regulate the class of immune response in vivo. Proc. Natl. Acad. Sci. 96: 1036.

Punnonen, J., Aversa, G., Cocks, B.G., McKenzie, A.N.J., Menon, S., Zurawski, G., Malefyt, R.D.W., and de Vries, J.E. 1993. Interleukin 13 induces interleukin 4-independent IgG4 and IgE synthesis and CD23 expression by human B cells. Proc. Nat1. Acad. Sci. 90: 3730-3734.

Ranger, A.M., Das, M.P., Kuchroo, V.K., and Glimcher, L.H. 1996. B7-2 (CD86) is essential for the development of interleukin-4 producing T cells. Int. Immunol. 8: 1549-1560.

Ranger, A.M., Hodge, M.R., Gravallese, E.M., Oukka, M., Davidson, L., Alt, F.W., de la Brousse, F.C., Hoey, T., Grusby, M., and Glimcher, L.H. 1998a. Delayed lymphoid repopulation with defects in IL-4-driven responses produced by inactivation of NFATc. Immunity 8: 125-134.

Ranger, A.M., Oukka, M., Rengarajan, J., and Glimcher, L.H. 1998b. Inhibitory function of two NFAT family members in lymphoid homeostasis and Th2 development. Immunity 9: 627-635.

Rao, Y. 1994. Conversion of a mesodermalizing molecule, the Xenopus Brachyury gene, into a neuralizing factor. Genes \& Dev. 8: 939-947.

Rao, A., Luo, C., and Hogan, P.G. 1997. Transcription factors of the NFAT family: Regulation and function. Annu. Rev. Immunol. 15: 707-747.

Reiner, S.L. and Seder, R.A. 1999. Dealing from the evolutionary pawnshop: How lymphocytes make decisions. Immunity 
11: $1-10$.

Rengarajan, J. and Glimcher, L.H. 2000. Transcriptional regulation of cytokine gene expression. In Cytokines and autoimmune diseases (ed. V.K. Kuchroo, D.A. Hafler, and N. Sarvetnick). (In press.) Humana Press, Totowa, NJ.

Richter, A., Lohning, M., and Radbruch, A. 1999. Instruction for cytokine expression in $\mathrm{T}$ helper lymphocytes in relation to proliferation and cell cycle progression. J. Exp. Med. 190: 1439-1450.

Rincon, M., Anguita, J., Nakamura, T., Fikrig, E., and Flavell, R.A. 1997. Interleukin (IL)-6 directs the differentiation of IL-4-producing CD4+ ${ }^{+}$T cells. J. Exp. Med. 185: 461-469.

Rincon, M., Enslen, H., Raingeaud, J., Recht, M., Zapton, T., Su, M.S., Penix, L.A., Davis, R.J., and Flavell, R.A. 1998. Interferon-gamma expression by Th1 effector $\mathrm{T}$ cells mediated by the p38 MAP kinase signaling pathway. EMBO I. 17: 28172829.

Rissoan, M.C., Soumelis, V., Kadowaki, N., Grouard, G., Briere, F., and de Waal Malefyt, R. 1999. Reciprocal control of T helper cell and dendritic cell differentiation. Science 283: $1183-1186$.

Riviere, I., Sunshine, M.J., and Littman, D.R. 1998. Regulation of IL-4 expression by activation of individual alleles. Immunity 9: 217-228.

Robinson, D., Shibuya, K., Mui, A., Zonin, F., Murphy, E., Sana, T., Hartley, S.B., Menon, S., Kastelein, R., Bazan, F., and O'Garra, A. 1997. IGIF does not drive Th1 development but synergizes with IL-12 for interferon- $\gamma$ production and activates IRAK and NF-кB. Immunity 7: 571-581.

Rodriguez-Esteban, C., Tsukui, T., Yonei, S., Magallon, J., Tamura, K., and Belmonte, J.C.I. 1999. The T-box genes Tbx4 and Tbx5 regulate limb outgrowth and identity. $\mathrm{Na}$ ture 398: 814-818.

Rogge, L., Barberis-Maino, L., Biffi, M., Passini, N., Presky, D.H., Gubler, U., and Sinigaglia, F. 1997. Selective expression of an interleukin-12 receptor component by human $\mathrm{T}$ helper 1 cells. J. Exp. Med. 185: 825-831.

Rogge, L., D'Ambrosio, D., Biffi, M., Penna, G., Minetti, L.J., Presky, D.H., Adorini, L., and Sinigaglia, F. 1998. The role of Stat4 in species-specific regulation of Th cell development by type I IFN's. J. Immunol. 161: 6567-6574.

Romagnani, S. 1992. Induction of TH1 and TH2 responses: A key role for the "natural" immune response? Immunol. Today 13: 379-381.

- 1994. Lymphokine production by human T cells in disease states. In Annual reviews of immunology, (ed. W.E. Paul, C.G. Fathman, and H. Metzger), pp. 227-257. Annual Reviews, Palo Alto, CA.

Rooney, J.W., Hodge, M.R., McCaffrey, P.G., Rao, A., and Glimcher L.H. 1994. A common factor regulates both Th1and Th2-specific cytokine gene expression. EMBO $I$. 13: 625-633.

Rooney, J.W., Hoey, T., and Glimcher, L.H. 1995a. Coordinate and cooperative roles for NF-AT and AP-1 in the regulation of the murine IL-4 gene. Immunity 2: 545-553.

Rooney, J., Sun, Y.-L., Glimcher, L.H., and Hoey, T. 1995b. Novel NFAT sites that mediate activation of the interleukin-2 promoter in response to T-cell receptor stimulation. Mol. Cell. Biol. 15: 6299-6310.

Rothenberg, E.V. and Ward, S.B. 1996. A dynamic assembly of diverse transcription factors integrates activation and celltype information for interleukin 2 gene regulation. Proc. Nat1. Acad. Sci. 93: 9358-9365.

Sabapathy, K., Hu, Y., Kallunki, T., Schreiber, M., David, J.P., Jochum, W., Wagner, E.F., and Karin, M. 1999. JNK2 is required for efficient T-cell activation and apoptosis but not for normal lymphocyte development. Curr. Biol. 9: 116-125. Sallusto, F., Lenig, D., Mackay, C., and Lanzavecchia, A. 1998. Flexible programs of chemokine receptor expression on human polarized $\mathrm{T}$ helper 1 and 2 lymphocytes. J. Exp. Med. 187: 875-883.

Salomon, B. and Bluestone, J.A. 1998. LFA-1 interaction with ICAM-1 and ICAM-2 regulates Th2 cytokine production. I. Immunol. 161: 5138-5142.

Satoskar, A.R., Okano, M., Connaughton, S., Raisanen, S., David, J.R., and Labow, M. 1998. Enhanced Th2-like responses in IL-1 type 1 receptor-deficient mice. Eur. I. Immunol. 28: 2066-2074.

Schweitzer, A.N., Borriello, F., Wong, R.C.K., Abbas, A.K., and Sharpe, A.H. 1997. Role of costimulators in T cell differentiation. J. Immunol. 158: 2713-2722.

Scott, P. 1991. IFN- $\gamma$ modulates the early development of Th1 and Th2 response in a murine model of cutaneous Leishmaniasis. J. Immunol. 147: 3149.

Seder, R.A. and Paul, W.E. 1994. Acquisition of lymphokineproducing phenotype by $\mathrm{CD}^{+}{ }^{+} \mathrm{T}$ cells. In Annual review immunology (ed. W.E. Paul, C.G. Fathman, and H. Metzger), pp. 635-673. Annual Reviews, Palo Alto, CA.

Seder, R.A., Gazzinelli, R., Sher, A., and Paul, W.E. 1993. IL-12 acts directly on $\mathrm{CD}^{+} \mathrm{T}$ cells to enhance priming for IFN- $\gamma$ production and diminishes IL-4 inhibition of such priming. Proc. Natl. Acad. Sci. 90: 10188-10192.

Shapiro, V.S., Truitt, K.E., Imboden, J.B., and Weiss, A. 1997. CD28 mediates transcriptional upregulation of the interleukin-2 (IL-2) promoter through a composite element containing the CD28RE and NF-IL-2B AP-1 sites. Mol. Cell. Biol. 17: 4051-4058.

Shapiro, V.S., Mollenauer, M.N., and Weiss, A. 1998. Nuclear factor of activated T cells and AP-1 are insufficient for IL-2 promoter activation: Requirement for CD28 up-regulation of RE/AP. J. Immunol. 161: 6455-6458.

Shaw, J., Utz, P., Durand, D., Toole, J., Emmel, E., and Crabtree, G. 1988. Identification of a putative regulator of early $\mathrm{T}$ cell activation genes. Science 241: 202-205.

Shibasaki, F., Price, E.R., Milan, D., and McKeon, F. 1996. Role of kinases and the phosphatase calcineurin in the nuclear shuttling of transcription factor NF-AT4. Nature 382: 370373.

Shibuya, K., Robinson, D., Zonin, F., Hartley, S.B., Macatonia, S.E., Somoza, C., Hunter, C.A., Murphy, K.M., and O'Garra, A. 1998. IL- $1 \alpha$ and TNF- $\alpha$ are required for IL-12-induced development of Th1 cells producing high levels of IFN- $\gamma$ in $\mathrm{BALB} / \mathrm{c}$ but not C57BL/ 6 mice. J. Immunol. 160: 1708-1716.

Shimoda, K., van Deursen, J., Sangster, M.Y., Sarawar, S.R., Carson, R.T., Tripp, R.A., Chu, C., Quelle, F.W., Nosaka, T., Vignali, D.A. et al. 1996. Lack of IL-4-induced Th2 response and IgE class switching in mice with disrupted Stat 6 gene. Nature 380: 630-633.

Sica, A., Dorman, L., Viggiano, V., Cippitelli, M., Ghosh, P., Rice, N., and Young, H.A. 1997. Interaction of NF-кB and NFAT with the interferon- $\gamma$ promoter. J. Biol. Chem. 272: 30412-30420.

Siebenlist, U., Durand, D.B., Bressler, P., Holbrook, N.J., Norris, C.A., Kamoun, M., Kant, J.A., and Crabtree, G.R. 1986. Promoter region of interleukin-2 gene undergoes chromatin structure changes and confers inducibility on chloramphenicol acetyltransferase gene during activation of T cells. Mol. Cell. Biol. 6: 3042-3049.

Siegel, M.D., Zhang, D.H., Ray, P., and Ray, A. 1995. Activation of the interleukin-5 promoter by cAMP in murine IL-4 cells requires the GATA-3 and CLEO elements. J. Biol. Chem. 270: $24548-24555$. 
Sloan-Lancaster, J., Steinberg, T.H., and Allen, P.M. 1997. Selective loss of the calcium ion signaling pathway in $\mathrm{T}$ cells maturing toward a $\mathrm{T}$ helper 2 phenotype. I. Immunol. 159: $1160-1168$

Smith, A.L. and Fazekas de St. Groth, B. 1999. Antigen-pulsed CD8a+ dendritic cells generate an immune response after subcutaneous injections without homing to the draining lymph node. J. Exp. Med. 189: 593-598.

Smith, J. 1997. Brachyury and the T-box genes. Curr. Opin. Genet. Dev. 7: 474-480.

Spranger, S., Ulmer, H., Troger, J., Jansen, O., Graf, J., Meinck, H.M., and Spranger, M. 1997. Muscular invovlement in the Holt-Oram syndrome. I. Med. Genet. 34: 978-981.

Subramanian, G., Kazura, J.W., Peralman, E., Jia, X., Malhotra, I., and King, C.L. 1997. B7-2 requirement for helminth-induced granuloma formation and CD4 type $2 \mathrm{~T}$ helper cell cytokine expression. J. Immunol. 158: 5914-5920.

Sweetser, M.T., Hoey, T., Sun, Y.L., Weaver, W.M., Price, G.A., and Wilson, C.B. 1998. The roles of nuclear factor of activated $T$ cells and Ying-Yang 1 in activation-induced expression of the interferon- $\gamma$ promoter in T cells. J. Biol. Chem. 273: 34775-34783.

Szabo, S.J., Gold, J.S., Murphy, T.L., and Murphy, K.M. 1993. Identification of cis-acting regulatory elements controlling interleukin-4 gene expression in T cells: Roles for NF-Y and NF-ATc. Mol. Cell. Biol. 13: 4793-4805.

Szabo, S.J., Jacobson, N.G., Dighe, A.S., Gubler, U., and Murphy, K.M. 1995. Developmental commitment to the Th2 lineage by extinction of IL-12 signaling. Immunity 2: 665675.

Szabo, S.J., Dighe, A.S., Gubler, U., and Murphy, K. 1997a. Regulation of the interleukin (IL)-12R $\beta 2$ subunit expression in developing $\mathrm{T}$ helper 1 (Th1) and Th2 cells. J. Exp. Med. 185: 817-824.

Szabo, S.J., Glimcher, L.H., and Ho, I.-C. 1997b. Genes that regulate interleukin-4 expression in T cells. Curr. Opin. Immunol. 9: 776-781.

Szabo, S.J., Kim, S.T., Costa, G.L., Zhang, X., Fathman, G.C., and Glimcher, L.H. 2000. A novel transcription factor, T-bet, directs Th1 lineage commitment. Cell 100: 655-669.

Takeda, K., Tanaka, T., Shi, W., Matsumoto, M., Minami, M., Kashiwamura, S., Nakanishi, K., Yoshida, N., Kishimoto, T., and Akira, S. 1996. Essential role of Stat6 in IL-4 signalling. Nature 380: 627-630.

Takeda, K., Tsutsui, H., Yoshimoto, T., Adachi, O., Yoshida, N., Kishimoto, T., Okamura, H., Nakanishi, K., and Akira, S. 1998. Defective NK cell activity and Th1 response in IL-18deficient mice. Immunity 8: 383-390.

Takemoto, N., Koyano-Nakagawa, N., Yokota, T., Arai, N., Miyatake, S., and Arai, K. 1998. Th2-specific DNase I-hypersensitive sites in the murine IL-13 and IL-4 intergenic region. Int. Immunol. 10: 383-390.

Takeuchi, J.K., Koshiba-Takeuchi, K., Matsumoto, K., VogelHopker, A., Naitoh-Matsuo, M., Ogura, K., Takahashi, N., Yasuda, K., and Ogura, T. 1999. Tbx5 and Tbx4 genes determine the wing/leg identity of limb buds. Nature 398: 810813.

Taki, S., Sato, T., Ogasawara, K., Fukuda, T., Sato, M., Hida, S., Suzuki, G., Mitsuyama, M., Shin, E.H., Kojima, S., Taniguchi, T., and Asano, Y. 1997. Multistage regulation of Th1type immune responses by the transcription factor IRF-1. Immunity 6: 673-679.

Tao, X., Constant, S., Jorritsma, P., and Bottomly, K. 1997. Strength of TCR signal determines the costimulatory requirements for Th1 and Th2 $\mathrm{CD}^{+}{ }^{+} \mathrm{T}$ cell differentiation. $J$. Immunol. 159: 5956-5963.
Tara, D., Weiss, D.L., and Brown, M.A. 1995. Characterization of the constitutive and inducible components of a T cell IL-4 activation responsive element. J. Immunol. 154: 4592-4602.

Taylor-Robinson, A.W. and Phillips, R.S. 1994. Expression of the IL-1 receptor discriminates Th2 from Th1 cloned CD4+ $\mathrm{T}$ cells specific for Plasmodium chabaudi. Immunology 81: 216-221.

Thierfelder, W.E., van Deursen, J.M., Yamamoto, K., Tripp, R.A., Sarawar, S.R., Carson, R.T., Sangster, M.Y., Vignali, D.A., Donherty, P.C., Grosveld, G.C., and Ihle, J.N. 1996. Requirement for Stat4 in interleukin-12-mediated responses of natural killer and T cells. Nature 382: 171-174.

Timmerman, L.A., Healy, J.I., Ho, S.N., Chen, L., Goodnow, C.C., and Crabtree, G.R. 1997. Redundant expression but selective utilization of nuclear factor of activated $\mathrm{T}$ cells family members. J. Immunol. 159: 2735-2740.

Ting, C.N., Olson, M.C., Barton, K.P., and Leiden, J.M. 1996. Transcription factor GATA-3 is required for development of the T-cell lineage. Nature 384: 474-478.

Todd, M.D., Grusby, M.J., Lederer, J.A., Lacy, E., Lichtman, A.H., and Glimcher, L.H. 1993. Transcription of the interleukin 4 gene is regulated by multiple promoter elements. J. Exp. Med. 177: 1663-1674.

Townsend, M.J., Fallon, P.G., Matthews, D.J., Jolin, H.E., and McKenzie, A.N.J. 2000. T1/ST2-deficient mice demonstrate the importance of $\mathrm{T} 1 / \mathrm{ST} 2$ in developing primary $\mathrm{T}$ helper cell type 2 responses. J. Exp. Med. 191: 1069-1075.

Trinchieri, G. 1993. Interleukin-12 and its role in the generation of Th1 cells. Immunol. Today 14: 335-338.

Tsuji-Takayama, K., Matsumoto, S., Koide, K., Takeuchi, M., Ikeda, M., Ohta, T., and Kurimoto, M. 1997. Interleukin-18 induces activation and association of p56(lck) and MAPK in a murine Th1 clone. Biochem. Biophys. Res. Commun. 237: $126-130$.

Ullman, K.S., Flanagan, W.M., Edwards, C.A., and Crabtree, G.R. 1991. Activation of early gene expression $\mathrm{T}$ lymphocytes by Oct-1 and an inducible protein. Science 254: 558-562.

Umlauf, S.W., Beverly, B., Lantz, O., and Schwartz, R.H. 1995. Regulation of interleukin 2 gene expression by CD28 costimulation in mouse T-cell clones: Both nuclear and cytoplasmic RNAs are regulated with complex kinetics. Mol. Cell. Biol. 15: 3197-3205.

Ward, S.B., Hernandez-Hoyos, G., Chen, F., Waterman, M., Reeves, R., and Rothenberg, E.V. 1998. Chromatin remodeling of the interleukin-2 gene: Distinct alterations in the proximal versus distal enhancer regions. Nucleic Acid Res. 26: 2923-2934.

Weber, M.L., Salgame, P., Hu, C., Davydov, I.V., Laur, O., Klevenz, S., and Krammer, P.H. 1998. Th2-specific protein/DNA interactions at the proximal nuclear factor-AT site contribute to the functional activity of the human IL-4 promoter. $J$. Immunol. 161: 1380-1389.

Wenner, C.A., Guler, M.L., Macatonia, S.E., O'Garra, A., and Murphy, K.M. 1996. Roles of IFN-gamma and IFN-alpha in IL-12-induced T helper cell-1 development. I. Immunol. 156: $1442-1447$

Wenner, C.A., Szabo, S.J., and Murphy, K.M. 1997. Identification of IL-4 promoter elements conferring Th2-restricted expression during $\mathrm{T}$ helper cell subset development. J. Immunol. 158: 765-773.

Wills-Karp, M., Luyimbazi, J., Xu, X., Schofield, B., Neben, T.Y., Karp, C.L., and Donaldson, D.D. 1998. Interleukin-13: Central mediator of allergic asthma. Science 282: 2258-2261.

Wu, C.Y., Demeure, C., Kiniwa, M., Gately, M., and Delespesse, G. 1993. IL-12 induces the production of IFN-gamma by neonatal human CD4 T cells. J. Immunol. 151: 1938. 
Xanthoudakis, S., Viola, J.P.B., Shaw, K.T.Y., Luo, C., Wallace, J.D., Bozza, P.T., Luk, D.C., Curran, T., and Rao, A. 1996. An enhanced immune response in mice lacking the transcription factor NFAT1. Science 272: 892-895.

Xu, D., Chan, W.L., Leung, B.P., Huang, F.-P., Wheeler, R., Piedrafita, D., Robinson, J.H., and Liew, F.Y. 1998a. Selective expression of a stable cell surface molecule on type 2 but not type 1 helper T cells. J. Exp. Med. 187: 787-794.

$\mathrm{Xu}$, D., Chan, W.L., Leung, B.P., Hunter, D., Schulz, K., Carter, R.W., McInnes, I.B., Robinson, J.H., and Liew, F.Y. 1998b. Selective expression and functions of interleukin 18 receptor on $\mathrm{T}$ helper (Th) type 1 but not Th2 cells. I. Exp. Med. 188: $1485-1492$

Xu, X., Sun, Y.L., and Hoey, T. 1996. Cooperative DNA binding and sequence-selective recognition conferred by the STAT amino-terminal domain. Science 273: 794-796.

Yang, D.D., Conze, D., Whitmarsh, A.J., Barrett, T., Davis, R.J., Rincon, M., and Flavell, R.A. 1998. Differentiation of CD4 ${ }^{+}$ $\mathrm{T}$ cells to Th1 cells requires MAP kinase JNK2. Immunity 9: $575-585$.

Yang, J., Murphy, T.L., Ouyang, W., and Murphy, K.M. 1999. Induction of interferon-gamma production in Th1 CD4+ T cells: Evidence for two distinct pathways for promoter activation. Eur. J. Immunol. 29: 548-555.

Ye, J., Cippitelli, M., Dorman, L., Ortaldo, J.R., and Young, H.A. 1996. The nuclear factor YY1 suppresses the human gamma interferon promoter through two mechanisms: Inhibition of AP1 binding and activation of a silencer element. Mol. Cell. Biol. 16: 4744-4753.

Yoshida, H., Nishina, H., Takimoto, H., Marengère, L.E.M., Wakeham, A.C., Bouchard, D., Kong, Y.-Y., Ohteki, T., Shahinian, A., Bachmann, M. et al. 1998. The transcription factor NF-ATc1 regulates lymphocyte proliferation and Th2 cytokine production. Immunity 8: 115-124.

Yoshimoto, T., Okamura, H., Tagawa, Y.-I., Iwakura, Y., and Nakanishi, K. 1997. Interleukin 18 together with interleukin 12 inhibits IgE production by induction of interferon- $\gamma$ production from activated B cells. Proc. Natl. Acad. Sci. 94: 3948-3953.

Yoshinaga, S.K., Whoriskey, J.S., Khare, S.D., Sarmiento, U., Guo, J., Horan, T., Shih, G., Zhang, M., Coccia, M.A., Kohno, T. et al. 1999. T-cell co-stimulation through B7RP-1 and ICOS. Nature 402: 827-832.

Young, H.A., Ghosh, P., Ye, J., Lederer, J., Lichtman, A., Gerard, J.R., Penix, L., Wilson, C.B., Melvin, A.J., McGurn, M.E., Lewis, D.B., and Taub, D.D. 1994. Differentiation of the T helper phenotypes by analysis of methylation state of the IFN- $\gamma$ gene. J. Immunol. 153: 3603-3610.

Zhang, D.H., Cohn, L., Ray, P., Bottomly, K., and Ray, A. 1997. Transcription factor GATA-3 is differentially expressed in murine Th1 and Th 2 cells and controls Th2-specific expression of the interleukin-5 gene. J. Biol. Chem. 272: 21597-21603.

Zhang, D.H., Yang, L., and Ray, A. 1998a. Differential responsiveness of the IL-5 and IL-4 genes to transcription factor GATA-3. J. Immunol. 161: 3817-3821.

Zhang, D.H., Yang, L., Cohn, L., Parkyn, L., Homer, R., Ray, P., and Ray, A. 1999. Inhibition of allergic inflammation in a murine model of asthma by expression of a dominant-negative mutant of GATA-3. Immunity 11: 473-482.

Zhang, F., Wang, D.Z., Boothby, M., Penix, L., Flavell, R.A., and Aune, T.M. 1998b. Regulation of the activity of IFN- $\gamma$ promoter elements during Th cell differentiation. J. Immunol. 161: 6105-6112.

Zhang, J.J., Vinkemeier, U., Gu, W., Chakravarti, D., Horvath, C.M., and Darnell, J.E.J. 1996. Two contact regions between Stat 1 and CBP/p300 in interferon gamma signaling. Proc.
Natl. Acad. Sci. 93: 15092-15096.

Zheng, W.-P. and Flavell, R.A. 1997. The transcription factor GATA-3 is necessary and sufficient for Th2 cytokine gene expression in CD4 T cells. Cell 89: 587-596.

Zhong, Z., Wen, Z., and Darnell, J.E. 1994. Stat3 and Stat4: Members of the family of signal transducers and activators of transcription. Proc. Natl. Acad. Sci. 91: 4806-4810.

Zingoni, A., Soto, H., Hendrick, J.A., Stoppacciaro, A., Storlazzi, C.T., Sinigaglia, F., D'Ambrosio, D., O'Garra, A., Robinson, D., Rocchi, M., Santoni, A., Zlotnik, A., and Napolitano, M. 1998. The chemokine receptor CCR8 is preferentially expressed in Th2 but not Th1 cells. J. Immunol. 161: 547-551. 


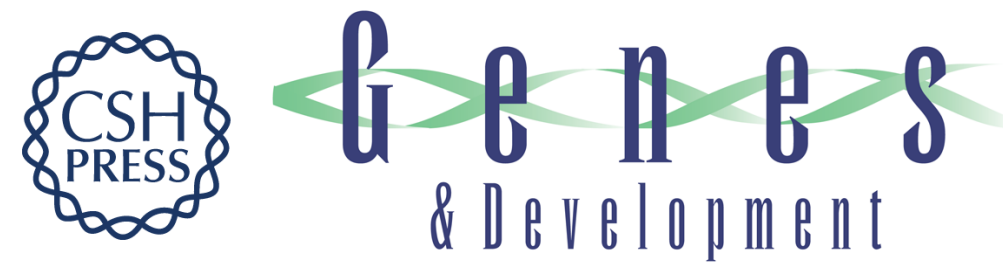

\section{Lineage commitment in the immune system: the T helper lymphocyte grows up}

Laurie H. Glimcher and Kenneth M. Murphy

Genes Dev. 2000, 14:

Access the most recent version at doi:10.1101/gad.14.14.1693

$\begin{array}{ll}\text { References } & \begin{array}{l}\text { This article cites } 244 \text { articles, } 138 \text { of which can be accessed free at: } \\ \text { http://genesdev.cshlp.org/content/14/14/1693.full.html\#ref-list-1 }\end{array}\end{array}$

License

Email Alerting Receive free email alerts when new articles cite this article - sign up in the box at the top Service right corner of the article or click here.

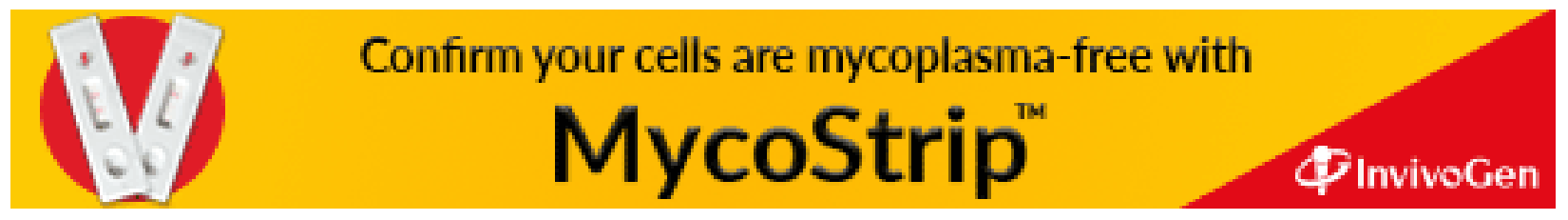

